Discussion Paper No. 17-020

\title{
Dynamics of Overqualification: Evidence from the Early Career of Graduates
}

Daniel Erdsiek

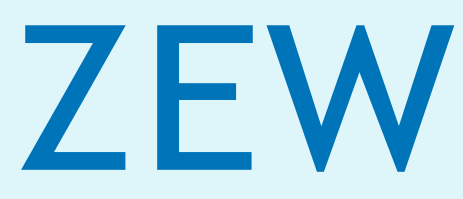

Zentrum für Europäische Wirtschaftsforschung $\mathrm{GmbH}$

Centre for European

Economic Research 
Discussion Paper No. 17-020

\title{
Dynamics of Overqualification: Evidence from the Early Career of Graduates
}

\author{
Daniel Erdsiek
}

Download this ZEW Discussion Paper from our ftp server:

http://ftp.zew.de/pub/zew-docs/dp/dp17020.pdf

Die Discussion Papers dienen einer möglichst schnellen Verbreitung von neueren Forschungsarbeiten des ZEW. Die Beiträge liegen in alleiniger Verantwortung der Autoren und stellen nicht notwendigerweise die Meinung des ZEW dar.

Discussion Papers are intended to make results of ZEW research promptly available to other economists in order to encourage discussion and suggestions for revisions. The authors are solely responsible for the contents which do not necessarily represent the opinion of the ZEW. 


\title{
Dynamics of Overqualification: Evidence from the Early Career of Graduates
}

\author{
Daniel Erdsiek* \\ ZEW Mannheim
}

April 2017

\begin{abstract}
This study analyses the persistence and true state dependence of overqualification, i.e. a mismatch between workers' qualifications and their jobs' educational requirements. Employing individual-level panel data for Germany, I find that overqualification is highly persistent among tertiary graduates over the first ten years of their career cycle. Accounting for unobserved heterogeneity, results from dynamic random-effects probit models suggest that only a small share of the observed persistence can be attributed to a true state dependence effect. Unobserved factors are found to be the main driver of the high persistence of overqualification. In particular, selection into initial overqualification at the start of the career is of high importance. Furthermore, overqualification persistence is shown to be partly attributable to observed heterogeneity in terms of ability and study characteristics.
\end{abstract}

JEL-Classification: I21, I23, J24.

Keywords: overqualification, overeducation, persistence, state dependence, dynamic random-effects probit.

\footnotetext{
* Centre for European Economic Research (ZEW) Mannheim, P.O. Box 103443, 68034 Mannheim, email: erdsiek@zew.de. For further information on projects of the author see www.zew.de/staff_der. I thank Melanie Arntz, Christina Gathmann, Reinhold Kesler, André Nolte, Bettina Peters, Patrick Schulte, Steffen Viete, and participants of the internal seminar at the University of Heidelberg for their valuable comments. This paper was written as part of the project "Adequate employment of graduates: An economic analysis of job match quality" supported within the programme "Economics of Science" by the German Ministry of Education and Research (BMBF, research grant 01PW11019). All remaining errors are my sole responsibility.
} 


\section{Introduction}

Labour markets of industrialised countries share the common feature that substantial shares of workers are holding jobs which are not commensurate to their educational attainment. Summarising previous studies, Leuven and Oosterbeek (2011) find that an average share of $30 \%$ of workers acquired a level of qualification exceeding the educational requirement of their current job. Consequently, these workers are formally overqualified for their job, i.e. they experience a vertical educational mismatch. This suboptimal allocation of workers across jobs may signal an inefficient allocation of skills in the labour market because available skills are not fully exploited. According to assignment theory allowing for skill-heterogeneity among workers and jobs (Sattinger, 1993), workers holding jobs below their qualification level cannot fully utilise their human capital and thus do not reach their individual production capacity. At the economy level, misallocations in the form of overqualification may imply significant productivity losses (McGowan and Andrews, 2015). Output losses may be particularly high if productivity is highly contingent on the precision of job matches and if different types of workers are poor substitutes (Gautier and Teulings, 2015). At the individual level, many studies infer the costs of overqualification from its effect on wages which are assumed to represent the marginal productivity of workers (Becker, 1964). Cross-sectional analyses consistently find that overqualified workers earn more than their co-workers in the same low-requirement job but less than equally educated individuals in adequate jobs (Duncan and Hoffman, 1981; Hartog, 2000). Panel studies accounting for skill-heterogeneity among equally educated workers provide mixed results. While some studies conclude that wage penalties only represent spurious correlations because overqualified workers have lower ability (Leuven and Oosterbeek, 2011; Tsai, 2010), other studies find that wage penalties diminish but remain significant after controlling for skill-heterogeneity (Kleibrink, 2015; Korpi and Tåhlin, 2009).

To what extent overqualification is detrimental at the economy or the individual level will strongly depend on its longevity. If overqualification occurs just transitorily at the start of the career before workers find suitable jobs, losses may only arise in the short-run until available skills are optimally allocated. In contrast, if workers are permanently overqualified, long-term losses may arise because of a continuous underutilisation of their human capital. In this case, private and public educational investments into skills which are permanently untapped, i.e. unproductive, may be partly wasted because of reduced returns in terms of wages or tax revenues. This is of particular relevance in the context of the publicly subsidised expansion of tertiary education induced by a strong increase in the demand for skills and the notion that human capital promotes economic growth. Shifts in the relative demand for high-skilled labour are considered to largely result from skill-biased technical change, i.e. changes in production processes favouring the employment of high-skilled workers. Skill demand may rise due to technical change embodied in capital goods, such as information and communication technologies 
(Michaels et al., 2014), or due to disembodied forms of technical change, such as organisational change (Caroli and Van Reenen, 2001). ${ }^{1}$ In order to meet the rising demand for skills, it is one of the main pillars of the European strategy for economic growth (EU2020) to ensure a steady increase in the supply of tertiary graduates (European Commission, 2010). At the aggregate level, overqualification of graduates may occur if the shift in supply is not balanced by the shift in demand for high-skilled labour. However, even in the absence of aggregate imbalances, overqualification at the individual level may arise as a consequence of worker and job skill-heterogeneity in conjunction with asymmetric information and labour market frictions inducing costly job search (Sattinger, 2012).

Predictions on the duration and, ultimately, the costs of overqualification at the individual level differ across related theories. According to career mobility theory (Sicherman, 1991), overqualification is only a short-term phenomenon and part of a human capital investment strategy of new labour market entrants. Workers deliberately choose jobs below their own level of education in order to acquire relevant on-the-job training and experience promoting upward mobility and a fast career progression. In contrast, further theories focus on labour market frictions and suggest that overqualification will be highly persistent at the individual level, e.g. because of segmented labour markets (Doeringer and Piore, 1971; Scherer, 2004). Descriptive findings based on panel data for graduates entering the labour market confirm a high persistence of overqualification and show that previously overqualified graduates are much more likely to be overqualified in the future (Verhaest and Velden, 2012). The observed persistence may partly arise as a consequence of constant individual-specific characteristics affecting the probability to be overqualified in every observation period, i.e. spurious state dependence. For instance, individuals may permanently hold low-requirement jobs because of an inferior level of human capital relative to equally educated individuals. In contrast, the persistence could be partly attributed to a behavioural effect such that past overqualification causally increases the probability of future overqualification, i.e. true state dependence. For instance, true state dependence of overqualification may arise because workers get trapped in a mismatch due to cognitive decline (De Grip et al., 2008), investments in specific human capital (Pissarides, 1994), or reduced job search effort on-the-job (Holzer, 1987). In terms of policy implications, it is crucial to detect whether overqualification arises due to differences in individual characteristics or because of true state dependence. If overqualification causally increases the probability of future overqualification, i.e. true state dependence is present, policy measures that prevent entry into or promote exits out of overqualification can induce a lasting reduction in the rate of overqualification. In contrast, if persistence arises solely due to constant individual characteristics, policies facilitating exits out of overqualification have little impact on future overqualification unless the factors causing overqualification are addressed directly.

\footnotetext{
$\overline{1}$ Other potential sources for rising skill demand include international trade (Feenstra and Hanson, 1999) or capital-skill complementarity (Krusell et al., 2000).
} 
The current study analyses the dynamic features of overqualification for the policy-relevant group of tertiary graduates. The main aim is to disentangle true state dependence from persistence arising due to differences in individual characteristics that are observed or unobserved. Dynamic models of labour market state choice which account for unobserved individual-specific effects face the problem of endogenous initial conditions. The "initial conditions problem" can be considered as an endogenous selection problem because individual-specific unobserved factors may affect both the persistence of a labour market state and the initial state in the first period available in the data (Heckman, 1981b). True state dependence is likely to be overestimated if potential endogeneity of the outcome in the first period is ignored (Chay and Hyslop, 2014). Therefore, I employ the dynamic random-effects probit model proposed by Wooldridge (2005). In order to integrate out the individual-specific effect, this estimator models the unobserved heterogeneity as a function of the initial condition, individual-specific explanatory variables, and a new random error that is uncorrelated with the initial condition.

The empirical analysis is based on panel data covering the first ten years of individual careers for university graduates in Germany (HIS-Graduate Panel). Interviews were conducted 1, 5, and 10 years after graduation and provide information on current overqualification and a rich set of explanatory variables such as university and school grades, field of study, or previous unemployment. Graduate overqualification is found to be considerably high over the observed time span. While $53 \%$ of the graduates who were overqualified in the previous interview remain overqualified in the next period, only $8 \%$ of previously well-matched graduates enter overqualification. Therefore, the raw state dependence observed in the data, i.e. the difference in the conditional probabilities to be overqualified, amounts to 45 percentage points. The dynamic effect of previous overqualification reduces to 34 percentage points when a rich set of observed characteristics is accounted for.

Accounting for unobserved heterogeneity, the results of the Wooldridge estimator suggest that a moderate share of the observed persistence can be attributed to a true state dependence effect. Previous overqualification experience is found to have a significant but small behavioural effect on future overqualification amounting to 3 percentage points. Furthermore, the results suggest that unobserved factors are the main driver of the high persistence of overqualification over the early career of graduates. In particular, unobserved characteristics driving the selection into the initial state of overqualification observed one year after graduation are strongly related to the probability to remain overqualified later on. Relevant unobserved factors might include preferences for particular job characteristics found in low-requirement jobs or labour market frictions such as regional immobility (Büchel and Van Ham, 2003).

Sensitivity analyses show that the findings on true state dependence are robust to the choice of the econometric model and the measure for educational mismatch. First, the estimations are replicated employing the estimator proposed by Heckman (1981b). The Heckman estimator differs from the Wooldridge estimator in the way how unobserved heterogeneity and the initial 
conditions are treated. Second, the baseline estimations are replicated using a measure for the mismatch in the field of education instead of the level of education.

The study contributes to the scarce literature on true state dependence of overqualification. A common feature of previous studies is that they rely on samples drawn from the entire working population observed at different stages of individual career cycles. Consequently, as opposed to the present study, they do not provide evidence for equally educated workers who enter the labour market and are observed over the early career cycle. Focussing on a sample of workers at the onset of their career is of particular relevance for testing theories hypothesising that overqualification is a short-term phenomenon among new labour market entrants, e.g. career mobility theory. The first available information on overqualification is observed much more closely to the real start of the labour market experience in the present study than in the few previous studies accounting for endogenous initial conditions. Furthermore, previous studies focus on rather short-term transitions between consecutive years, while the present study analyses dynamics of overqualification between observations approximately 5 years apart. This eases a problem studies based on annual data often face, i.e. one single spell of overqualification may span two consecutive years inducing spurious state dependence.

The remainder of this chapter is organised as follows. Section 2 provides a review of the related theoretical and empirical literature. Section 3 introduces the data and provides descriptive statistics. Section 4 describes the econometric model employed to analyse the true state dependence of overqualification. Section 5 provides the results and Section 6 provides the sensitivity analyses. Section 7 discusses the results and concludes.

\section{Background Discussion}

This section provides a review of the related literature. First, an overview on the theoretical explanations for the existence and, in particular, the longevity of overqualification is provided. Second, the results of previous empirical studies on the dynamics of overqualification are summarised and discussed.

\subsection{Theoretical Background}

Several labour market theories suggest that overqualification is only a temporary phenomenon. Human capital theory predicts that workers will always earn their marginal product because production processes are continuously adapted to available input factors (Becker, 1964; Mincer, 1974). Therefore, underutilisation of human capital should not occur in the labour market and overqualification will not exist in equilibrium. However, overqualification could temporarily arise if the labour market is in disequilibrium because of a sudden increase in the supply of better educated workers inducing a decline in their relative wages. In this situation, employers could 
hire more qualified, i.e. more productive, workers into positions previously held by individuals with lower educational levels (Borghans and Grip, 2000). However, overqualification will disappear once individuals respond to lower returns to education by reducing their investments into education and firms adjust their production processes in order to make use of the higher supply of skilled workers. According to human capital theory, prolonged overqualification can only be explained as representing a statistical artifact arising from the fact that human capital is observed only incompletely.

According to matching theory, the job match quality cannot be foreseen by workers and firms because of imperfect information (Jovanovic, 1979). Because job match quality is an "experience good", workers might accept jobs that turn out to not match their skills. As a consequence, mismatched workers will start to search for new positions and improve their job matches until they find an appropriate position. In a similar vein, search theories stress the costly and time-intensive nature of job search activities (Burdett, 1978). Workers might accept a job offer below their educational level temporarily while pursuing their search on-the-job. Therefore, overqualification is only transitory within these frameworks and will predominantly occur at the beginning of the workers' careers.

As suggested by the career mobility theory, overqualification might also be a part of a planned career path (Sicherman and Galor, 1990; Sicherman, 1991). Workers might deliberately enter jobs for which they are overqualified in order to acquire further skills through on-the-job training which promote a rapid career development. From this point of view, overqualification at the start of the career is short-lived and might serve as a stepping-stone to better jobs in the future within or outside the firm. The career mobility theory provides explanations for both the employee's as well as the employer's motivation for accepting a transitory phase of overqualification. In addition to higher starting wages, potential returns to investments in high levels of education include better prospects of promotion within firms or an upward move to other firms. Employees maximizing their earnings over their career cycle might accept a lower pay at the start of their contract in exchange for a favourable position in the firm's promotion queue assuring higher future earnings. In case promotions fail to appear as planned, workers will move to another firm. From a firm perspective, employers might be willing to accept this agreement since they have the opportunity to test whether the new workers are eligible for higher and more demanding positions within the firm at lower costs during the overqualification period. According to the theory, mismatches are resolved by either the employee or the employer in the long-run.

On the contrary, other theories focus on labour market frictions and suggest that overqualification may be persistent at the individual level. In the job-competition model (Thurow, 1972), an applicant's place in the queue for a promising job is largely determined by his education. Under imperfect information, employers use education as a proxy for future job performance and trainability. From the employer's perspective, a higher level of an applicant's education implies lower training costs. Based on the employer's preference to hire those applicants who 
are likely to be the cheapest to train, overqualified candidates have a head start in the job queue because they raise the highest expectations in terms of returns to further educational investments. This model, thus, gives an explanation for the employer's motivation for preferring job candidates with schooling exceeding the job requirements. Concerning the supply-side, the model does not directly explain the motivation of workers to accept a job offer below their educational attainment since overqualified workers cannot realise a wage premium. The formal qualification only determines the position in the job queue, but does not affect the wage offer. However, the job-competition model suggests another potential supply-side explanation for enduring overqualification. Individuals might acquire the highest level of education in order to secure the best possible position in the job queue. If consequently the educational attainment of workers increases, a reduction in the returns to schooling contributes to a crowding-out of less qualified workers into low wage jobs or entirely out of the labour market. Since investments are not reduced despite of lower returns to education in order to retain the position in the job queue, a higher share of high-skilled individuals will end up in jobs below their skill level. Furthermore, according to the model, most actual required skills are learned through experience or on-the-job training. Therefore, workers in low-level occupations cannot compete for more demanding positions suggesting that the state of overqualification is likely to be permanent.

The effect of geographic restrictions on the probability to be overqualified is emphasised by the spatial mobility theory (Büchel and Van Ham, 2003). Due to costs of commuting and migration, individuals are assumed to search for jobs in their local (regional) labour market. Since the number of suitable jobs will be lower in smaller, regional labour markets than in the global market, the probability of overqualification is assumed to depend on the spatial mobility of job seekers. Empirical support for the spatial mobility theory is provided by the finding that overqualification is less likely in larger and thicker local labour markets (Abel and Deitz, 2015; Büchel and Van Ham, 2003). As a consequence, overqualification caused by geographic restrictions could persist as long as spatial flexibility of workers or job opportunities in a given local labour market are not improved.

The assignment model is concerned with the problem of allocating individuals with different skill levels to jobs with varying complexity (Sattinger, 1993). In practice, mismatches are likely to occur because the distribution of workers and their skill levels will not fully match the distribution of available jobs and their skill requirements. Furthermore, workers might accept a job offer above their reservation wage before finding the optimal match because of imperfect information. In the same vein, employers might hire an applicant before finding the optimal one. Therefore, the phenomenon of overqualification will be an inevitable outcome of such a complex allocation process. According to the assignment theory, the workers' productivity does not only depend on the individual human capital, but also on the match quality between the individual characteristics and job tasks. Better skilled workers have a comparative advantage in more complex jobs. Mismatches occur if workers are not assigned to a job type where their 
comparative advantages are best utilised. Consequently, high-skilled workers holding a job with low skill requirements will not reach their individual productive capacity. The assignment model therefore contradicts both the job-competition model suggesting that solely the job characteristics determine productivity and the human capital model suggesting that solely the worker's skills predict productivity (Hartog, 1986). Concerning the longevity of overqualification, models combining assignment with costly search have shown that job mismatch might be a long-lasting phenomenon at the individual level (Albrecht and Vroman, 2002; Dolado et al., 2009; Teulings and Gautier, 2004).

Hiring decisions of employers will be governed by productivity-based considerations. From a firm perspective, hiring overqualified candidates might induce productivity losses due to lower job satisfaction and motivation, or a higher incidence of shirking and absenteeism (Büchel, 2001). Furthermore, a higher probability of frequent job changes could result in a loss of companyspecific human capital and induce transaction costs for finding new job candidates. Recent studies employing firm-level panel data, however, find that firm productivity is positively affected by the level of required education as well as by additional years of overeducation (Kampelmann and Rycx, 2012; Mahy et al., 2015). Therefore, overqualified workers seem to be more productive than their well-matched colleagues. This result is in line with the literature on wage effects of overqualification finding significant returns to surplus years of education that, however, are lower than the returns to required schooling. Taken together, these findings support the hypothesis that overqualified workers earn more than their well-matched job colleagues because they are more productive than the latter. Mahy et al. (2015) conclude that the significant positive effect of overqualification on firm productivity seems to indicate that additional skills and capabilities acquired in school outweigh potential effects of job dissatisfaction. Hiring applicants with higher skills than necessary for the job could also be used as a form of insurance strategy in order to ensure a continuous and uninterrupted supply of high-skilled labour to the firm (Cedefop, 2012; Desjardins and Rubenson, 2011). These findings suggest that employers might have an incentive to hire and retain overqualified employees. This demand side effect might contribute to the persistence of overqualification (Büchel, 2002).

As frequently discussed in the literature, overqualification may also arise due to individual heterogeneity among workers who attained the same level of education (Hartog, 2000). If the relevant individual-specific factors are persistent over time, they could lead to a high degree of overqualification persistence. Since this does not imply a causal dependence between previous and future overqualification experience, this mechanism is referred to as spurious state dependence (Heckman, 1981a). In line with the human capital theory, individuals might be overqualified because of low ability for their level of qualification. This situation then might be consistent with a well-functioning labour market rather than indicating a form of market failure. Since skill formation also depends on other factors than formal education, the measure of overqualification might neglect other important components of the workers' human capital 
required for demanding job tasks. In line with this human capital compensation hypothesis, several studies have shown that individuals with an inferior level of ability and skills are more likely to be overqualified (Büchel and Pollmann-Schult, 2004; Chevalier and Lindley, 2009). Consequently, a share of the overqualified workers might just be "apparently mismatched" such that observed overqualification does not come along with a significant underutilisation of skills (Chevalier, 2003; Green and McIntosh, 2007; Green and Zhu, 2010). The fact that a transition into a formally adequate job might not be an option for this group of workers might translate into highly persistent overqualification and, thus, into spurious state dependence.

Another reason for enduring overqualification may be that workers voluntarily choose positions below their own level of education. They might have preferences for non-pecuniary job characteristics available in low-requirement positions. For instance, these workers might prefer an easier workload than they can find in jobs which they are adequately educated for. Employing data on UK graduates, McGuinness and Sloane (2011) find that overqualified male workers are more likely to value and to opt for jobs which offer a greater balance with family life. This group is also found to place a lower emphasis on high earnings. This suggests the occurrence of compensating wage effects, i.e. a lower wage for an overqualified worker could be explained by better non-wage characteristics provided by the job (Sattinger, 2012). As long as the workers' preferences for low-requirement jobs remain unchanged over time, this could induce another source for spurious state dependence of overqualification.

Alternatively, overqualification persistence could arise because of a causal effect of previous overqualification experience implying true state dependence. Being overqualified in one period may in itself increase the probability to be overqualified in the next period, even if compared to another identical individual who was not overqualified in the base period. Several mechanisms could explain such a state dependence effect of overqualification. Most of these mechanisms have been discussed in the literature on state dependence in low wage and unemployment but seem to be similarly relevant for overqualification which is often associated with wage penalties and the underutilisation of skills. ${ }^{2}$ Overqualification may alter the process of human capital acquisition and job-specific human capital investments may lock overqualified workers into low-requirement positions (Pissarides, 1994). Workers' productivity may also be negatively affected by enduring overqualification for another reason. Knowledge and skills untapped during longer periods of overqualification may depreciate or become devalued because of changing skill requirements in jobs matching the educational level of workers (Heckman and Borjas, 1980). De Grip et al. (2008) find a significant relationship between overqualification and cognitive decline. Therefore, job mismatch may send negative signals to potential future employers who use previous overqualification experience as a screening device for the applicants' future productivity. According to McCormick (1990), the signal may be even more negative for overqualification

\footnotetext{
${ }^{2}$ In this related literature, scarring effects of low pay and unemployment are well-documented (Arulampalam et al., 2000; Stewart and Swaffield, 1999).
} 
than for unemployment. ${ }^{3}$ In his model, unemployed high productive individuals will specialise in job search for high-skilled jobs rather than take an interim low-requirement position, while employers may use the individuals' job search strategy as a productivity signal if individual differences in productivity are unknown to them. Finally, overqualification spells may change the individuals' preferences or motivation to hold adequate jobs. Experiencing overqualification may lead to a lower perception of the own market value discouraging workers to apply for more adequate jobs in the future (Stewart and Swaffield, 1999). Overqualified workers may also be locked in low-quality jobs because of a reduced job search effort on-the-job (Holzer, 1987) or segmented labour markets (Doeringer and Piore, 1971).

\subsection{Empirical Evidence}

The longevity of mismatches is the focus of a growing strand of the empirical overqualification literature. Several studies have tried to assess the validity of the career mobility hypothesis stating that overqualification serves as a stepping-stone to better future jobs. In favour of the career mobility theory, early studies using simple cross-sectional data sets often found that experience and tenure are negatively correlated with the probability to be overqualified (Alba-Ramirez, 1993; Sicherman, 1991). Following studies, however, have found no evidence for a significant difference between promotion prospects of overqualified employees and adequately educated employees in similar jobs (Büchel, 2001). Employing wage growth as a more direct measure of upward mobility, Büchel and Mertens (2004) provide a test of the career mobility theory for Germany. Contrary to the theoretical prediction, they find that overqualified employees experience less wage growth than workers with the same level of qualification holding adequate jobs. In a similar study for Sweden, Korpi and Tåhlin (2009) also find no evidence for a higher wage growth among overqualified workers relative to well-matched workers in similar low-requirement jobs.

In recent years, cohort studies of school leavers offer new empirical tests on the career mobility at the time of labour market entry. Focusing on unemployed Flemish school leavers, Baert et al. (2013) show that taking up a job below the educational attainment significantly delays the transition into adequate employment. Based on a multi-national survey of college graduates in 13 European countries and Japan, Verhaest and Velden (2012) analysed the persistence of overqualification over the first five years of the career cycle. Among those graduates who were overqualified in their initial employment in the year 2000 between $30 \%$ (the Netherlands) and $58 \%$ (Switzerland) have remained overqualified in the year 2005. In contrast, on average only $5 \%$ of the graduates with a matching initial job have been found to be overqualified after five years.

\footnotetext{
${ }^{3}$ Kroft et al. (2013) provide experimental evidence for negative duration dependence of unemployment in the US. Sending fictitious job applications varying in past unemployment experience to real job postings, they find that the likelihood of receiving a callback for an interview significantly decreases with the length of the unemployment spell.
} 
Similarly, Frenette (2004) finds that a share of $74 \%$ of Canadian graduates who were overqualified two years after graduation remained in that state three years later. Battu et al. (1999) make use of survey data collected 1, 5, and 11 years after graduation for a sample of UK graduates who completed their study programme in 1985. They find that approximately $30 \%$ of the graduates never had a job that required a tertiary degree during the observed time span. Finding a substantial rate of raw state dependence in the data sets employed, these studies suggest that overqualification is a persistent phenomenon rather than a transitory state for a substantial share of workers at the start of the career. However, these studies do not provide evidence whether the observed persistence arises because of time-invariant unobserved heterogeneity, i.e. spurious state dependence, or a genuine behavioural effect of previous overqualification, i.e. true state dependence.

A few recent studies employ more advanced panel estimation models in order to evaluate the size of true state dependence of overqualification by controlling for unobserved individual heterogeneity. Employing annual German data from 2000 to 2008, Blázquez and Budría (2012) find a very high persistence rate of overqualification. While $86 \%$ of previously overqualified workers remain overqualified in the next year, only $2 \%$ of previously well-matched workers enter overqualification. Therefore, the difference in the conditional probabilities to be overqualified, i.e. the raw state dependence, amounts to 84 percentage points. Estimating a trivariate probit model, the authors show that a share of $18 \%$ of this raw state dependence can be attributed to a true state dependence effect. Employing the dynamic random-effects model proposed by Wooldridge (2005), the study by Boll et al. (2016) also finds significant state dependence of overqualification in the German labour market for the time period from 1984 to 2011. The results are robust to the inclusion of two different measures for overqualification. Using the same estimation approach, Kiersztyn (2013) provides evidence for overqualification being a self-perpetuating state in Poland from 1988 to 2008. The risk of being overqualified is found to be four times higher for those workers who have been overqualified in the preceding wave relative to previously well-matched workers. Furthermore, Mavromaras and McGuinness (2012) find that skill mismatch, i.e. a situation where workers report that their skills are not fully utilised in their job, exhibits true state dependence in Australia. ${ }^{4}$

Only few studies have analysed which characteristics affect transitions into and out of overqualification over the path of individual careers. Using a panel data set for American workers, Clark et al. (2014) find that cognitive ability is a relevant factor for overqualification dynamics. Higher scores in a cognitive ability test have a positive and significant effect on the hazard rate out of overqualification. The authors also provide evidence for considerable differences in the dynamics of overqualification with respect to race, gender, and unemployment history. A higher rate of overqualification persistence is more prevalent among black workers and

\footnotetext{
${ }^{4}$ The skill mismatch variable is constructed using the individuals' responses to the following question: "To what extent do you agree with the following statement: I use many of my skills and abilities in my current job" (Mavromaras and McGuinness, 2012).
} 
female workers. Furthermore, longer duration of previous unemployment delays the transition into a matching job. For Germany, Blázquez and Budría (2012) have shown that the probability to remain mismatched is significantly affected by the workers' personality traits. For instance, high scores in the Big Five personality dimensions conscientiousness and extraversion decrease the probability to remain overqualified.

A common feature of these studies on state dependence of overqualification is that their results rely on samples of workers drawn from the entire working population observed at different stages of individual career cycles. Consequently, they do not measure state dependence for cohorts of equally educated workers who enter the labour market and are observed over the early years of the career cycle. It is the main aim of the present study to contribute to the reviewed literature by providing evidence on the extent of true state dependence of overqualification over the early career cycle of university graduates in Germany.

\section{Data}

The empirical analysis is based on two cohorts of the HIS-Graduate Panel covering university graduates who completed their study programme in 1997 and 2001, respectively. ${ }^{5}$ It is a longitudinal nationwide study of tertiary graduates in Germany which surveys individuals of each cohort 1 year, 5 years, and 10 years after graduation. ${ }^{6}$ This data set has several advantageous features with respect to my analysis. In comparison to survey data covering the entire working population, focusing the analysis on the policy-relevant group of graduates does not produce small sample sizes. This is of particular relevance in the context of the study since it focuses on the dynamics of overqualification which is a labour market outcome only a rather small share of graduates will be affected by. Only a large sample size allows to adequately analyse the subsequent labour market progression for the group of initially overqualified individuals. In addition, the individuals are jointly observed over the first ten years of their career cycles after entering the labour market as tertiary graduates and they face the same overall economic situation. In order to further increase the comparability of graduates, I exclude individuals who were older than 35 years at the time of graduation or who obtained the university entrance certificate abroad. After deleting observations with missing values in the relevant variables, the size of the remaining sample amounts to 5,987 graduates. $^{7}$ In order to test for systematic differences in sample attrition, I tested whether characteristics observed in the first interview

\footnotetext{
${ }^{5}$ Hochschul-Informations-System (2007): HIS-Graduate Panel 1997. GESIS Data Archive, Köln. ZA4272, dx.doi .org/10.4232/1.4272;

Hochschul-Informations-System (2010): HIS-Graduate Panel 2001. GESIS Data Archive, Köln. ZA5186, doi : 10.4232/1.5186

${ }^{6}$ I thank the staff of the German Centre for Higher Education Research and Science Studies (DZHW) for the opportunity to access the data from the third interview not included in the scientific use files.

7 According to the survey reports, the following number of interviews have been conducted in the respective waves for cohort 1997 (2001): wave 1: 9,582 (8,103); wave 2: 6,220 (5,427); wave 3: 5,477 (4,734) (Fabian and Briedis, 2009; Fabian et al., 2013). The reduction in sample size in the present study is mostly driven by
} 
significantly differ between individuals who dropped out of the survey and individuals who participated in all three interviews. Unfortunately, I find that stayers have significantly better grades than drop-outs so that a selection of more able graduates into the sample might be present. In contrast, I find no significant difference in the hourly wage rate at the time of the first interview between stayers and drop-outs. Since the incidence of overqualification at the time of the first interview is slightly lower for stayers than for drop-outs, however, the results on overqualification rates and persistence over the observed time span might be downward biased. Potential biases caused by sample attrition are not accounted for in the present analysis.

\subsection{Dependent Variable}

The focal dependent variable in this analysis is graduate overqualification. Overqualification indicates the occurrence of a vertical educational mismatch, such that workers hold a higher qualification than is required by their job or position. Three different measures for overqualification have been employed in the literature. They differ in the way how they evaluate the level of qualification that is needed for a job and are based on either the respondents' subjective assessments, realized matches within occupational classifications, or job analysts' ratings (see e.g. Hartog, 2000, for an overview). The present study employs a subjective measure of overqualification which is based on the respondents' self-assessment of the level of educational attainment required for their job. In particular, the graduates were asked whether they hold a position for which a tertiary degree is a conventional requirement. Graduates are defined to be overqualified if they indicate that their job usually does not require a tertiary degree. An indicator variable takes the value 1 for overqualified graduates and 0 , otherwise. The binary overqualification status is observed at each of the three survey waves conducted 1 year, 5 years, and 10 years after graduation for both cohorts. ${ }^{8}$ The subjective measure of overqualification has one main advantage that is of particular relevance in the dynamic context of the study. As Hartog (2000) and others pointed out, the subjective measure captures specific job characteristics that only the job holder can assess and, thus, is not based on information aggregated at any occupational level. Therefore, in contrast to the objective measures defined for occupational classifications, a change in the overqualification status is possible within occupations because the tasks that have to be performed by the respondent have changed. However, since this measure relies on the workers' self-assessment, it is sensitive to potential differences in the individuals' perception of job requirements. Therefore, I have to assume that the assessment of job requirements does

missing values in control variables. The raw dynamics of overqualification based on all available observations do not significantly differ from those based on the estimation sample.

8 Only small fractions of $3 \%, 2 \%$, and $1 \%$ of the graduates in the estimation sample have been unemployed at the time of wave 1, 2, and 3, respectively. Respondents currently unemployed at the time of the survey were asked to refer to their last job after graduation when they answer questions regarding their "current" job (including the question on overqualification). As a robustness check, all estimations provided in this chapter have been re-run excluding all currently unemployed respondents but the results remain qualitatively unchanged. 
not systematically change over time at the individual level. Overall, the longitudinal cohort study design allows to analyse the dynamic features of overqualification over the first ten years of individual career cycles.

\subsection{Explanatory Variables}

Since this study focuses on the underlying mechanisms of overqualification persistence, it is important to include relevant characteristics that may determine mismatches and could contribute to spurious state dependence. Based on the vast empirical literature concerned with potential determinants of overqualification, this study incorporates a rich set of explanatory variables.

Individuals holding the same level of qualification may differ in (innate) ability and skills. In line with the human capital compensation hypothesis, several studies have shown that individuals with an inferior level of ability and skills are more likely to be overqualified (Büchel and Pollmann-Schult, 2004; Chevalier and Lindley, 2009). Low-ability graduates lacking the skills required for graduate jobs may contribute to a high persistence of overqualification because of their high probability to stay in their formally inadequate position. In order to account for differences in ability and skills among the graduates in the sample, this study incorporates school leaving examination grades and university grades as proxy variables. Although grades are surely an imperfect proxy for ability, previous research shows that cognitive as well as non-cognitive skills are relevant predictors of grades (Almlund et al., 2011; Poropat, 2009). School leaving examination grades may proxy primarily for differences in general skills and ability. Since the procedures of the school leaving examination differ across the 16 federal states in Germany, school grades are standardised within federal states. Concerning the differences in occupation specific skills that are relevant for holding graduate jobs in a given field, especially university grades may be a sound proxy variable. University grades are standardised within fields of study and university types in order to account for substantial differences in the distribution of grades along these dimensions.

Study characteristics, such as field of study or university type, are relevant determinants of overqualification among graduates in several countries (Berlingieri and Erdsiek, 2012; Dolton and Vignoles, 2000; Green and McIntosh, 2007). In Germany, individuals can choose between two tracks of tertiary education. They can either enrol at traditional universities or at universities of applied sciences. In general, traditional universities are academically more demanding than the practically oriented study programmes at universities of applied sciences. A dummy variable is generated taking the value 1 for graduates from universities of applied sciences and 0, otherwise. The respondents' fields of study are divided into four subject groups. The first subject group consists of the three subjects Medicine, Law, and Teaching which require a state examination as finals and can solely be studied at traditional universities. The remaining subjects can be 
studied at both university types and are divided into three groups, namely Science, Technology, Engineering, and Mathematics (STEM subjects), Business \& Economics, and Social \& Cultural Sciences. The individuals' study duration is another potentially important study characteristic that future employers may use as productivity-related signal. Since average durations of programmes vary across subjects and university types, the individuals' time needed for course completion measured in semesters is standardised within subject groups and university types.

The family background of graduates may also affect the probability to find an adequate job at the outset of the career cycle (Erdsiek, 2016). As a proxy for various forms of capital transmitted within families, I include a dummy variable into the analysis indicating whether at least one of the graduate's parents obtained a tertiary degree. Social background may be related to the individuals' motivation or aspiration, may provide advantageous social networks for finding promising jobs, or may ease the pressure to take a job offer due to financial constraints.

Concerning the role of gender for the occurrence of overqualification, previous results are mixed (Leuven and Oosterbeek, 2011). Most studies for Germany find a higher prevalence of overqualification among women than men (Büchel, 2001). According to the theory of differential overqualification (Frank, 1978), married women in smaller labour markets may have a higher risk of overqualification because of the optimisation of dual job search for couples. Married female workers may be tied movers or tied stayers since their job search is undertaken under the condition that the job search of their husbands is optimised because they are often the primary earners. For Germany, Büchel and Battu (2003) find that married women have a higher risk of being overqualified, especially when they live in rural areas. In order to analyse whether female graduates obtain a higher risk of overqualification over the early career cycle holding the characteristics constant, a gender dummy is included in the estimation models. Furthermore, in order to analyse whether the role of potential determinants as well as overqualification dynamics differ according to gender, the estimations are performed for splitted samples.

So far, all presented explanatory variables are time-constant. In the main part of the analysis, three time-variant explanatory variables are accounted for. Changes in job preferences and family responsibilities over the observed time span may occur because of parenthood and marital status, partly discussed in the context of the theory of differential overqualification above. On the one hand, parenthood as well as getting married may increase the individuals' reservation wage which is a relevant factor for the decision to accept a job offer below the own qualification level. On the other hand, increased family responsibilities may change the preferences for specific job characteristics, such as working hours and overall workload, in a way that less demanding jobs become a more favourable option. ${ }^{9}$ Changes in parenthood and marital status are observed in each wave of the survey, i.e. 1, 5, and 10 years after graduation.

\footnotetext{
${ }^{9}$ For instance, studies on the effects of maternity leave on subsequent labour market participation emphasise that mothers may reassess their work preferences after first birth (e.g. Fitzenberger et al., 2016).
} 
In addition, unemployment experience is included as a time-variant explanatory variable. Based on calender information provided by the respondents, the duration of previous unemployment experience (in number of months) is calculated for each of the three waves. The related literature on unemployment scarring commonly finds that past unemployment causally increases the probability of future unemployment and also the probability to be low paid (Cappellari and Jenkins, 2008a; Stewart, 2007). Therefore, individuals exiting unemployment are more likely to only find jobs with low skill requirements. In a similar vein, previously unemployed university graduates may have problems to find an adequate job because of the negative productivity-related signal for potential future employers. A further potential mechanism could be that prolonged unemployment decreases the reservation wage and graduates are more likely to accept low-requirement job offers below their educational level (Stewart and Swaffield, 1999). For Germany, Boll et al. (2016) find that previous unemployment increases the risk of overqualification.

\subsection{Descriptive Statistics}

Table 1 provides summary statistics for the relevant variables. One year after graduation $(t=1)$, a substantial share of $17 \%$ of the graduates is working in jobs that do not require a tertiary degree. After four more years $(t=5)$, the average share of overqualified graduates has slightly decreased to $16 \%$. Finally, ten years after graduation $(t=10)$, the rate of graduate overqualification has fallen to a share of $14 \%$. At the aggregate level, job mismatch thus seems to occur throughout the early career of graduates in Germany with a tendency to decrease with potential labour market experience.

Turning to persistence at the individual level, Table A.1 in the Appendix depicts the frequency of observed patterns of overqualification dynamics over the three time periods. The majority of graduates $(72 \%)$ was holding appropriate jobs at each $t$. In contrast, $6 \%$ of the graduates have been permanently overqualified in every $t$. The columns 5 and 6 provide the distribution of dynamic patterns conditional on the initial state of overqualification. $86 \%$ of initially wellmatched graduates remained in adequate employment 5 and 10 years after graduation. However, among initially overqualified graduates only $41 \%$ were matched in both later periods and approximately one third remained overqualified over the observed time span.

The transition matrices in Table A.2 provide the probabilities for entering and exiting overqualification. Among graduates who were overqualified in $t=1$, a share of $50 \%$ has managed to find a matching job five years after graduation, while the other half of this group remained stuck in a mismatch (top panel). The probability to be overqualified in $t=5$ is considerably lower for previously well-matched graduates. Only $10 \%$ of the graduates who found a matching job at the outset of their professional career hold a formally inadequate job in $t=5$. Taken together, the probability to be overqualified in $t=5$ is 40.4 percentage points higher for graduates already 
Table 1: Summary Statistics

\begin{tabular}{|c|c|c|c|c|}
\hline & Mean & $\mathrm{SD}$ & Min & $\operatorname{Max}$ \\
\hline \multicolumn{5}{|l|}{ Dependent Variable } \\
\hline Overqualification $(t=1)$ & 0.17 & 0.37 & 0 & 1 \\
\hline Overqualification $(t=5)$ & 0.16 & 0.37 & 0 & 1 \\
\hline Overqualification $(t=10)$ & 0.14 & 0.35 & 0 & 1 \\
\hline \multicolumn{5}{|l|}{ Time-invariant controls } \\
\hline Female & 0.50 & 0.50 & 0 & 1 \\
\hline University grade ${ }^{a}$ & 3.03 & 0.62 & 1.0 & 4.0 \\
\hline School grade ${ }^{a}$ & 2.83 & 0.63 & 1.0 & 4.0 \\
\hline Study duration ${ }^{b}$ & 11.17 & 2.56 & 6 & 20 \\
\hline University of applied sciences & 0.28 & 0.45 & 0 & 1 \\
\hline Business Administration \& Economics & 0.16 & 0.36 & 0 & 1 \\
\hline Medicine, Law, \& Teaching & 0.23 & 0.42 & 0 & 1 \\
\hline STEM subjects & 0.44 & 0.50 & 0 & 1 \\
\hline Social \& Cultural science & 0.18 & 0.38 & 0 & 1 \\
\hline Age at graduation & 26.92 & 2.35 & 22 & 35 \\
\hline Parents high-skilled & 0.51 & 0.50 & 0 & 1 \\
\hline Cohort: 1997 & 0.49 & 0.50 & 0 & 1 \\
\hline \multicolumn{5}{|l|}{ Time-variant controls ${ }^{c}$} \\
\hline Married & 0.41 & 0.50 & 0 & 1 \\
\hline Children & 0.34 & 0.48 & 0 & 1 \\
\hline Months unemployed & 1.73 & 3.77 & 0 & 53 \\
\hline Observations & 5987 & & & \\
\hline
\end{tabular}

Note: $t$ depicts the time of observation 1,5 , and 10 years after graduation; ${ }^{a}$ The German grading system is reversed, so that 1 is the lowest grade and 4 is the highest, i.e. the best, grade; ${ }^{b}$ Measured in semesters; ${ }^{c}$ Overall statistics are presented. Source: HIS-Graduate Panel 1997, 2001

overqualified in the previous period relative to previously well-matched graduates. Therefore, overqualification exhibits a substantial rate of raw state dependence during the first five years of graduates' careers. The raw state dependence between $t=5$ and $t=10$ is even higher because the probability to enter overqualification decreases while the risk of remaining mismatched increases (bottom panel). If the transitions are pooled over the first 10 years of the career cycle, raw state dependence amounts to 45 percentage points.

In Table A.3, the incidence of overqualification over the early career of graduates is provided for relevant subgroups of the sample. In particular, the sample is stratified according to gender, field of study, and quartiles of the university grade. The rate of overqualification is higher among female graduates than among male graduates in each time period. For both groups, the incidence of overqualification has reduced after 10 years of labour market experience. Considerable differences according to the field of study show a clear pattern which endures over the observed time span. The lowest rate of overqualification is observed for the fields Medicine, Law, and Teaching (approx. 4\%). The incidence of overqualification is considerably higher among graduates of the STEM subjects (13\%). However, overqualification is remarkably more likely in the fields Business Administration \& Economics (28\%) and Social \& Cultural 
Science (27\%). A clear pattern also evolves regarding the distribution of overqualified graduates across the quartiles of university grades. ${ }^{10}$ The incidence of overqualification gradually decreases from the lowest to the top quartile. Graduates in the lowest quartile are more than twice as likely to become overqualified than graduates in the top quartile. Again, while the rate of overqualification decreases for each quartile over time, the pattern across quartiles remains unchanged.

\section{Methodology}

The descriptive evidence presented in the previous section has shown that overqualification is highly persistent at the individual level, however no conclusion on the underlying mechanisms can be drawn from these results. The main aim of this study is to disentangle true state dependence from persistence arising due to differences in individual characteristics that are observed or unobserved. This section describes the econometric model and discusses related issues concerning implementation and data structure.

\subsection{Econometric Model}

Using dynamic random-effects probit models, the importance of a behavioural effect from past overqualification experience on future overqualification can be evaluated by controlling for individual heterogeneity (observed and unobserved). The treatment of unobserved heterogeneity and initial conditions is an important issue for the estimation of such models including the lagged dependent variable. Ignoring unobserved heterogeneity that exhibits persistence over time will lead to an overstatement of the true state dependence of overqualification.

The econometric model can be summarised as follows. Let $y_{i t}^{*}$ be the latent propensity for individual $i$ to be overqualified at time $t$. The latent propensity depends on the previous (realised) overqualification experience $y_{i, t-1}$, on observable explanatory variables summarised in the row vector $x_{i t}$ and on individual-specific attributes $\mu_{i}$ that are unobservable and time-invariant. An individual is observed to be overqualified, i.e. $y_{i t}=1$, if $y_{i t}^{*}$ exceeds a constant threshold which is assumed to be zero. The model is given by: ${ }^{11}$

$$
\begin{aligned}
& y_{i t}^{*}=\gamma y_{i, t-1}+x_{i t} \beta+\mu_{i}+\varepsilon_{i t} \quad i=1, \ldots, N, \quad t=2, \ldots, T \\
& y_{i t}=I\left[y_{i t}^{*}>0\right]
\end{aligned}
$$

\footnotetext{
${ }^{10}$ Note that university grades are standardised within fields of study and university types in order to account for substantial differences in the distribution of grades along these dimensions.

${ }^{11}$ Note that the model is presented in its standard notation indicating the lagged dependent variable as $y_{i, t-1}$. Due to the time structure of the data and following the notation used so far, the lagged dependent variable will be indicated by $y_{i, t-5}$ in the results section.
} 
where $\varepsilon_{i t}$ represents an idiosyncratic error term. It is assumed that $\varepsilon_{i t} \mid y_{i 1}, \ldots, y_{i, t-1}, x_{i}$ is $i . i . d$. as $N(0,1)$ and that $\varepsilon_{i t} \perp\left(y_{i 1}, x_{i}, \mu_{i}\right)$ with $x_{i}=\left(x_{i 2}, \ldots, x_{i T}\right)$. In such a model, the coefficient of the lagged dependent variable, $\gamma$, is interpreted as measuring the "structural" or true state dependence (Heckman, 1981a). "Spurious" state dependence due to permanent unobserved heterogeneity is accounted for by the term for constant individual-specific attributes $\mu_{i}$. In the present study, this term may be interpreted to capture differences in the individuals' unobserved ability or preferences for specific job characteristics.

The estimation of this model requires to account for the initial conditions problem. It is caused by the presence and correlation between the past value of the dependent variable and the unobserved heterogeneity term in the equation. Treating the initial conditions as exogenous would lead to an overstatement of the true state dependence effect if the initial conditions are correlated with $\mu_{i}$ (Chay and Hyslop, 2014). In order to integrate out the individual-specific effect, its relationship with the outcome in the initial period $y_{i 1}$ has to be specified. As suggested by Wooldridge (2005), one possibility is to assume that $y_{i 1}$ is random and to specify the distribution of $\mu_{i}$ conditional on $y_{i 1}$ and $x_{i}$ which leads to the joint density of $\left(y_{i 2}, \ldots, y_{i T}\right) \mid y_{i 1}, x_{i}$. Following this estimation strategy, it is assumed that the individual-specific effect depends on the initial condition and the strictly exogenous variables as follows:

$$
\mu_{i}=\alpha_{0}+\alpha_{1} y_{i 1}+\bar{x}_{i} \alpha_{2}+a_{i}
$$

The inclusion of the time-averages of the observed explanatory variables $\bar{x}_{i}=\frac{1}{T-1} \sum_{t=2}^{T} x_{i t}$ accounts for potential correlation between the unobserved heterogeneity and the time-variant explanatory variables as suggested by correlated random-effects models (Chamberlain, 1984; Mundlak, 1978). ${ }^{12}$ In this type of random-effects models, it is possible to estimate the effect of a change in $x_{i t}$ by holding the time-averages fixed. It is assumed that the error term $a_{i}$ is i.i.d. as $N\left(0, \sigma_{a}^{2}\right)$ and that $a_{i} \perp\left(y_{i 1}, \bar{x}_{i}\right)$. Thus, the distribution of the individual heterogeneity is specified as follows:

$$
\mu_{i} \mid\left(y_{i 1}, \bar{x}_{i}\right) \sim N\left(\alpha_{0}+\alpha_{1} y_{i 1}+\bar{x}_{i} \alpha_{2}, \sigma_{a}^{2}\right)
$$

Under these conditions, the probability to be overqualified is given by:

$$
P\left(y_{i t}=1 \mid y_{i 1}, \ldots, y_{i, t-1}, x_{i}, a_{i}\right)=\Phi\left(\gamma y_{i, t-1}+x_{i t} \beta+\alpha_{0}+\alpha_{1} y_{i 1}+\bar{x}_{i} \alpha_{2}+a_{i}\right)
$$

\footnotetext{
${ }^{12}$ The original Wooldridge model includes all values of the time-varying explanatory variables at each period (except the initial period). Most studies rely on the within-means of the time-varying explanatory variables instead. As shown by Rabe-Hesketh and Skrondal (2013), this specification does not lead to biases. They find that biases of the Wooldridge model in short panels documented by Akay (2012) are caused by including values of the initial period into the computation of time-averages. In line with Rabe-Hesketh and Skrondal (2013), I therefore use time-averages excluding the initial period. As a robustness check, the original Wooldridge model including leads and lags is also estimated and presented.
} 
As shown by Wooldridge (2005), integrating out $a_{i}$ yields a likelihood function with the same structure as in the standard random-effects model including the initial condition $y_{i 1}$ and the time-averaged $\bar{x}_{i}$ as additional explanatory variables in each time period $t$. Incorporating the augmented set of explanatory variables, standard random-effects probit estimation methods can be employed to estimate $\gamma, \beta, \alpha_{0}, \alpha_{1}, \alpha_{2}$ and $\sigma_{a}^{2} .{ }^{13}$

If $\gamma$ is estimated to be significantly greater than zero, true state dependence is present such that a previous experience of overqualification causally increases the probability to be overqualified in the next period. Due to the non-linearity of the model, however, the size of the state dependence effect cannot be gauged directly from the estimated coefficients. Therefore, the average partial effect (APE) for the lagged dependent variable is calculated in order to evaluate the extent of true state dependence. The fact that individual heterogeneity is unobserved is problematic for the estimation of partial effects. One way to overcome this problem is to estimate the APE under the assumption that the individual heterogeneity $\mu_{i}$ takes its average value. $E\left(\mu_{i}\right)=\alpha_{0}+\alpha_{1} E\left(y_{i 1}\right)+E\left(\bar{x}_{i}\right) \alpha_{2}$ and can be consistently estimated by $\left.\widehat{E(\mu}_{i}\right)=\widehat{\alpha}_{0}+\widehat{\alpha}_{1} \bar{y}_{1}+\bar{x} \widehat{\alpha}_{2}$ where $\bar{y}_{1}=\sum_{i=1}^{N} y_{i 1}$ and $\bar{x}=\sum_{i=1}^{N} \bar{x}_{i}$. The APE for the binary lagged dependent variable (previous overqualification) can be calculated as the discrete change in the probability to be overqualified as the dummy variable changes from 0 to 1 :

$$
\widehat{A P E}=\Phi\left[\widehat{\gamma}+x_{i} \widehat{\beta}+\widehat{\alpha}_{0}+\widehat{\alpha}_{1} \bar{y}_{1}+\bar{x} \widehat{\alpha}_{2}\right]-\Phi\left[x_{i} \widehat{\beta}+\widehat{\alpha}_{0}+\widehat{\alpha}_{1} \bar{y}_{1}+\bar{x} \widehat{\alpha}_{2}\right]
$$

\subsection{Implementation and Data Structure}

While only scarcely employed in the overqualification literature, dynamic random-effects probit models accounting for unobserved heterogeneity have been widely used in related studies concerned with state dependence of low wage or unemployment (Arulampalam and Stewart, 2009). As compared to most of these studies, the structure of the data used in the present analysis differs with respect to several aspects. Most studies on state dependence use more than 3 waves of annual data for a sample of the entire working population at various stages of individual career cycles. In contrast, my data set comprises 3 waves conducted approximately 5 years apart. Therefore, I observe changes in the individuals' labour market status over the medium-run rather than annual short-run transitions. Due to the longer duration between the interviews, the advantage of covering the first ten years of individual career cycles comes at the cost of observing the individuals at only three points in time. As opposed to this drawback, the increased time lag between interviews eases a problem studies employing annual data will often face. Spurious state dependence may occur if a single spell of the labour market outcome investigated, e.g. unemployment, may span two consecutive years for a substantial share of individuals. For instance, Arulampalam et al. (2000) take this problem into account and report

\footnotetext{
$\overline{{ }^{13} \text { For instance, the xtprobit command in Stata. }}$
} 
that over one third of the unemployment spells in their annual data set lasted longer than one year. As a further difference to most studies on state dependence, my data set solely comprises university graduates such that differences in the level of educational attainment do not occur in contrast to samples drawn from the entire working population. Therefore, I concentrate the analysis on the policy-relevant group of tertiary graduates and only compare individuals that are equally educated. Finally, the individuals are observed over the first ten years of their career cycles after entering the labour market as university graduates. Therefore, the initial condition is observed much more closely to the real start of the labour market experience than in most previous studies. Nevertheless, accounting for the initial conditions problem remains important. Even if the entire history of the process of overqualification experience is observed it would be a strong assumption that unobserved ability or preferences are independent from the initial state of overqualification (Wooldridge, 2005).

As already presented in the previous sections, the data set includes a rich set of explanatory variables that may affect the risk of being overqualified. Some of these explanatory variables do not vary over time at the individual level, such as the proxies for ability, the characteristics of the study programme, or the family background. As suggested by Wooldridge (2005), time-constant explanatory variables can be included in the dynamic random-effects model in order to increase explanatory power. However, the model is not able to separately identify the partial effects of the time-constant variables from their partial correlation with the unobserved individual heterogeneity.

The time-variant regressors included in the model are assumed to be strictly exogenous, conditional on the individual-specific unobserved effect $\mu_{i}$. This generally rules out potential feedback effects from changes in the outcome variable on future values of explanatory variables (Wooldridge, 2000). Despite the fact that explanatory variables are often choice variables, studies allowing for feedback effects by relaxing the strict exogeneity assumption are scarce. Focusing on state dependence in poverty, Biewen (2009) allows for potential feedback effects from poverty to future employment status and from poverty to future household composition. The author concludes that in the context of poverty the assumption of strict exogeneity is violated for these explanatory variables and that ignoring feedback effects may lead to biased estimates of the state dependence effect. However, most studies concerned with state dependence in various labour market outcomes assume strict exogeneity for all explanatory variables. For instance, Arulampalam et al. (2000) and other studies focusing on state dependence of unemployment do not account for the possibility that the time-variant regressors marital status and number of children may depend in part on past unemployment experience. In comparison to the context of the present study, feedback effects from unemployment on future explanatory variables may be more likely and more severe than potential feedback effects from overqualification spells in which individuals still are active in the labour market. Therefore, I assume that marital status and parenthood are not affected by earlier overqualification experience. Furthermore, it is 
assumed that overqualification does not affect future unemployment experience. This assumption may be violated if, conditional on the individual-specific unobserved effect, overqualification experience reduces the individual's chances to find any job, for instance due to negative signals for employers.

\section{Results}

This section provides the results of the empirical analysis. As a starting point, the first subsection provides the results from a simple dynamic pooled probit model taking only observed heterogeneity into account. The second subsection provides the main results from the dynamic random-effects probit model taking the selection into the initial condition and unobserved heterogeneity into account.

\subsection{Observed Heterogeneity}

This subsection presents the results from a simple dynamic pooled probit model including the lagged overqualification status as a determinant for future overqualification experience. Here, it is assumed that the lagged overqualification status is exogenously given. A stepwise inclusion of individual characteristics into the model allows us to gauge the relevance of observed heterogeneity for the persistence from changes in the coefficient of the lagged dependent variable.

As shown in the first specification in Table 2, previous overqualification is strongly related to future overqualification. ${ }^{14}$ Controlling only for cohort membership and gender, previously overqualified graduates obtain a 44 percentage points higher probability to be overqualified in the next period. This resembles the raw state dependence shown and discussed in the data section. The average partial effect of the lagged dependent variable is moderately reduced by 2 percentage points after including sociodemographic characteristics as well as previous unemployment spells into the model. Parental background, age at graduation, and unemployment experience are significantly related to overqualification. In contrast to most studies concerned with state dependence of labour market outcomes, I am able to include further explanatory variables concerning the study programme and individual ability. Accounting for differences across university types and fields of study in specification 3, the effect of previous overqualification is substantially reduced to 36 percentage points. Specification 4 additionally includes the proxy variables for ability resulting in a further reduction of the dynamic effect. Taken together, approximately one fifth of the average partial effect of previous overqualification can be explained by observed heterogeneity because the state dependence effect is reduced by 10 percentage points in specification 4 as compared to specification 1 . Heterogeneity concerning study characteristics

\footnotetext{
${ }^{14}$ Since the lagged dependent variable is included, the estimates are based on overqualification status five years as well as ten years after graduation as dependent variables. The standard errors are clustered at the individual level.
} 
Table 2: Results, Dynamic Pooled Probit

\begin{tabular}{lcccccccc}
\hline \hline & \multicolumn{7}{c}{ Dependent Variable: Overqualification } \\
\cline { 2 - 8 } & $(1)$ & & $(2)$ & & $(3)$ & & $(4)$ \\
\hline Overqualification $(t-5)$ & $0.442^{* * *}$ & $(0.013)$ & $0.423^{* * *}$ & $(0.013)$ & $0.360^{* * *}$ & $(0.013)$ & $0.342^{* * *}$ & $(0.013)$ \\
Female & $0.014^{* *}$ & $(0.006)$ & $0.018^{* * *}$ & $(0.006)$ & $0.024^{* * *}$ & $(0.006)$ & $0.022^{* * *}$ & $(0.006)$ \\
University grade & & & & & & & $-0.019^{* * *}$ & $(0.003)$ \\
School grade & & & & & & & $-0.008^{* *}$ & $(0.003)$ \\
Study duration & & & & & & & $0.007^{* *}$ & $(0.003)$ \\
U. applied sciences & & & & & $0.022^{* * *}$ & $(0.007)$ & $0.020^{* * *}$ & $(0.007)$ \\
BusAdmin/Econ & & & & ref. & & ref. & \\
Med/Law/Teach & & & & $-0.123^{* * *}$ & $(0.007)$ & $-0.125^{* * *}$ & $(0.007)$ \\
STEM subjects & & & & $-0.057^{* * *}$ & $(0.008)$ & $-0.058^{* * *}$ & $(0.008)$ \\
Soc/Cult science & & & & $-0.022^{* * *}$ & $(0.008)$ & $-0.020^{* *}$ & $(0.008)$ \\
Age at grad. $<27$ & & $-0.030^{* * *}$ & $(0.006)$ & $-0.025^{* * *}$ & $(0.006)$ & $-0.012^{*}$ & $(0.007)$ \\
Parents high-skilled & & $-0.018^{* * *}$ & $(0.006)$ & -0.008 & $(0.006)$ & -0.005 & $(0.006)$ \\
Married & & -0.005 & $(0.007)$ & -0.005 & $(0.007)$ & -0.004 & $(0.007)$ \\
Children & & 0.011 & $(0.007)$ & $0.013^{*}$ & $(0.007)$ & $0.012^{*}$ & $(0.007)$ \\
Months unemployed & & $0.004^{* * *}$ & $(0.001)$ & $0.004^{* * *}$ & $(0.001)$ & $0.004^{* * *}$ & $(0.001)$ \\
\hline Log. Lik. & -4116.3 & -4068.7 & & -3933.4 & & -3897.2 & \\
Obs. Indiv. & 5987 & 5987 & & 5987 & & 5987 & \\
Obs. Total & 11974 & 11974 & & 11974 & & 11974 & \\
\hline \hline
\end{tabular}

Note: Pooled Probit estimation; Average partial effects; Standard errors clustered at the individual level; Previous period indicated by $(t-5)$; Significant at $1 \%^{* * *}$, significant at $5 \%^{* *}$, significant at $10 \% *$.

and individual ability seems to be particularly relevant. ${ }^{15}$ The question to what extent the remaining dynamic effect of 34 percentage points can be attributed to unobserved heterogeneity or to true state dependence is analysed in the next subsection.

\subsection{Main Results}

This subsection provides the results from the dynamic random-effects probit model. Employing this econometric model, selection into initial overqualification as well as individual heterogeneity is taken into account in order to estimate the true state dependence effect. The results on the extent of true state dependence of overqualification are presented in Table 3. For the complete sample (specification 1), the average partial effect of the lagged overqualification experience is significant and amounts to 3 percentage points. This implies that even after controlling for observed and unobserved characteristics, graduates are on average 3 percentage points more likely to be overqualified at time $t$ if they have already experienced overqualification in $t-5 .^{16}$ Therefore, I find evidence for a true state dependence effect of graduate overqualification. However, the size of the causal effect of previous overqualification experience is substantially smaller than the observed raw state dependence of 45 percentage points. It is also much smaller

\footnotetext{
${ }^{15}$ The results remain unchanged if random-effects models are estimated instead of pooled probit models or if the sample is splitted for female and male graduates.

${ }^{16}$ Note again that $t-5$ indicates the lagged dependent variable even though the actual time lag between the first and second interview amounts to approximately 4 years.
} 
Table 3: Results, Wooldridge Dynamic RE Probit

\begin{tabular}{|c|c|c|c|c|c|c|}
\hline \multirow[b]{3}{*}{ Overqualification $(t-5)$} & \multicolumn{6}{|c|}{ Dependent Variable: Overqualification } \\
\hline & \multicolumn{2}{|c|}{$\begin{array}{l}\text { All } \\
(1)\end{array}$} & \multicolumn{2}{|c|}{$\begin{array}{c}\text { Female } \\
(2)\end{array}$} & \multicolumn{2}{|c|}{$\begin{array}{c}\text { Male } \\
(3)\end{array}$} \\
\hline & $0.029^{* *}$ & $(0.014)$ & 0.031 & $(0.019)$ & 0.028 & $(0.022)$ \\
\hline Overqualification $(t=1)$ & $0.234^{* * *}$ & $(0.024)$ & $0.220^{* * *}$ & $(0.031)$ & $0.254^{* * *}$ & $(0.038)$ \\
\hline Female & $0.019^{* * *}$ & $(0.006)$ & & & & \\
\hline University grade & $-0.019^{* * *}$ & $(0.003)$ & $-0.023^{* * *}$ & $(0.005)$ & $-0.015^{* * *}$ & $(0.004)$ \\
\hline School grade & $-0.008^{* *}$ & $(0.003)$ & $-0.014^{* * *}$ & $(0.005)$ & -0.003 & $(0.004)$ \\
\hline Study duration & $0.006^{* *}$ & $(0.003)$ & $0.009^{* *}$ & $(0.005)$ & 0.004 & $(0.004)$ \\
\hline U. applied sciences & $0.019^{* * *}$ & $(0.007)$ & $0.023^{* *}$ & $(0.011)$ & $0.017^{*}$ & $(0.009)$ \\
\hline BusAdmin/Econ & ref. & & ref. & & ref. & \\
\hline Med/Law/Teach & $-0.099^{* * *}$ & $(0.006)$ & $-0.117^{* * *}$ & $(0.010)$ & $-0.082^{* * *}$ & $(0.008)$ \\
\hline STEM subjects & $-0.055^{* * *}$ & $(0.008)$ & $-0.057^{* * *}$ & $(0.013)$ & $-0.053^{* * *}$ & $(0.011)$ \\
\hline Soc/Cult science & $-0.019^{* *}$ & $(0.008)$ & $-0.028^{* *}$ & $(0.012)$ & -0.008 & $(0.013)$ \\
\hline Age at grad. $<27$ & -0.010 & $(0.007)$ & -0.005 & $(0.010)$ & $-0.016^{*}$ & $(0.009)$ \\
\hline Parents high-skilled & -0.006 & $(0.006)$ & -0.006 & $(0.009)$ & -0.005 & $(0.008)$ \\
\hline Married & -0.003 & $(0.010)$ & -0.006 & $(0.014)$ & 0.000 & $(0.014)$ \\
\hline Children & 0.007 & $(0.010)$ & 0.018 & $(0.014)$ & -0.003 & $(0.014)$ \\
\hline Months unemployed & 0.001 & $(0.001)$ & 0.001 & $(0.002)$ & 0.001 & $(0.003)$ \\
\hline Mean: Married & -0.002 & $(0.013)$ & -0.003 & $(0.018)$ & -0.003 & $(0.018)$ \\
\hline Mean: Children & 0.009 & $(0.013)$ & 0.013 & $(0.019)$ & 0.008 & $(0.018)$ \\
\hline Mean: Months unemployed & $0.003^{* *}$ & $(0.002)$ & $0.004^{* *}$ & $(0.002)$ & 0.002 & $(0.003)$ \\
\hline$\sigma$ & 1.201 & $(0.101)$ & 1.366 & $(0.150)$ & 1.023 & $(0.138)$ \\
\hline$\rho$ & 0.591 & $(0.041)$ & 0.651 & $(0.050)$ & 0.512 & $(0.067)$ \\
\hline Log. Lik. & -3827.1 & & -1920.5 & & -1894.3 & \\
\hline Obs. Indiv. & 5987 & & 3009 & & 2978 & \\
\hline Obs. Total & 11974 & & 6018 & & 5956 & \\
\hline
\end{tabular}

Note: Random-effects probit estimation; Average partial effects; Standard errors in parentheses; Previous period indicated by $(t-5)$; Initial condition indicated by $(t=1) ; \rho$ : estimate of the cross-period correlation of the composite error term $a_{i}+\varepsilon_{i t}$; Significant at $1 \%^{* * *}$, significant at $5 \%{ }^{* *}$, significant at $10 \% *$.

than the average partial effect of lagged overqualification if only the observed heterogeneity is accounted for (34 percentage points). ${ }^{17}$ The results thus suggest that most of the raw state dependence is due to unobserved heterogeneity across graduates rather than due to a causal dynamic impact. Therefore, unobserved factors seem to be the main driver of overqualification persistence over the early career for graduates in Germany. The size of the true state dependence effect is nearly the same for both female and male graduates, however, the effect loses its significance in the gender-specific models presented in specification 2 and 3.

The effect of the initial condition, i.e. overqualification experience 1 year after graduation, is highly significant and much larger than the effect for the lagged dependent variable in all three specifications. This implies a substantial correlation between the graduates' initial overqualification status and the unobserved heterogeneity. In contrast to comparable studies on state dependence effects, initial conditions are actually observed at the beginning of individual

\footnotetext{
${ }^{17}$ See Table A.2 for the raw state dependence and Table 2 for the estimated state dependence effect if only observed heterogeneity is accounted for.
} 
labour market careers in the current study. The results suggest that most of the observed persistence of overqualification is attributable to the initial selection into inadequate job matches based on unobserved factors.

The average partial effects for the observed explanatory variables show that female graduates significantly obtain a 2 percentage points higher probability to be overqualified than their male peers. Graduates with higher ability are less likely to be overqualified. This holds for school grades that may proxy primarily for differences in general skills and ability as well as for university grades that may proxy for occupation specific skills that are relevant for holding graduate jobs in a given field. Graduates who needed a relatively long time to complete their study programme, as measured by the standardised study duration in months, are significantly more likely to be overqualified. Workers who graduated from a university of applied sciences are more likely to be mismatched than graduates from traditional universities, even when differences in the fields of study are accounted for. In comparison to graduates in Business Administration \& Economics, graduates in the other subjects are more likely to be adequately matched. In addition to their time-specific values, the model includes the averages for the time-variant explanatory variables. Only the time-averaged duration of unemployment experience is significant indicating a correlation to the unobserved heterogeneity for female graduates.

To check the robustness of the estimated size of the true state dependence effect, Table A.4 provides further specifications of the dynamic model for the complete sample. First, specification 1 includes the lags and leads of the time-variant explanatory variables as proposed in the original form of the Wooldridge estimator. The average partial effect of the lagged dependent variable, however, remains unchanged. Second, unemployment experience is excluded from the model since previous overqualification may exhibit potential feedback effects on future unemployment spells leading to biased estimates (Biewen, 2009). Again the main results remain unchanged. Third, the estimated effect of the lagged dependent variable only slightly increases if study characteristics and ability are excluded and only basic sociodemographic controls are included in the model. However, the significant negative effect of the initial overqualification experience increases considerably illustrating the high relevance of study characteristics and ability for the selection into early overqualification. Furthermore, the effect of parental education increases and becomes significant signalling that these individual characteristics are relevant pathways for family background effects on overqualification (Erdsiek, 2016).

\section{Sensitivity Analyses}

This section provides further robustness checks for the main results. First, the analysis is replicated using an alternative econometrical model that differs in the way of modelling unobserved heterogeneity and solving the initial conditions problem (Heckman, 1981b). Second, the analysis is replicated employing another measure for job mismatch, i.e. horizontal mismatch. 


\subsection{Heckman Model}

For dynamic non-linear models with unobserved individual-specific effects, another approach for handling the initial conditions problem has been proposed by Heckman (1981b). ${ }^{18}$ He suggested to model the initial outcome of the dependent variable, $y_{i 1}$, jointly with the subsequent outcomes of the dependent variable, $y_{i 2}, \ldots, y_{i T}$. In order to integrate out the unobserved effect $\mu_{i}$, he suggested to approximate the unknown distribution of $y_{i 1} \mid \mu_{i}, x_{i}$. In the latent variable form, the Heckman model can briefly be summarized as follows:

$$
\begin{array}{llrl}
y_{i 1}^{*}=z_{i} \lambda+\theta \mu_{i}+\varepsilon_{i 1} & i=1, \ldots, N, & t=1 \\
y_{i t}^{*}=\gamma y_{i, t-1}+x_{i t} \beta+\mu_{i}+\varepsilon_{i t} & i=1, \ldots, N, & t=2, \ldots, T
\end{array}
$$

where $z_{i}$ is a row vector of covariates including $x_{i 1}$ and additional exogenous instruments for the initial condition. By construction, $\mu_{i}$ and $\varepsilon_{i 1}$ are orthogonal to one another. It is assumed that the initial observation $y_{i 1}$ is uncorrelated with $\varepsilon_{i t}$ and also that $\varepsilon_{i 1}$ is uncorrelated with the $x_{i t}$ for all $i$ and $t$. Moreover, it is assumed that both $\varepsilon_{i 1}$ and $\mu_{i}$ are normally distributed, the former with variance 1 and the latter with variance $\sigma_{\mu}^{2}$. A test of exogeneity of the initial condition in this model is provided by the test of $\theta=0$.

Equations (7) and (8) together specify a complete model for $\left(y_{1}, y_{2}, \ldots, y_{T}\right)$. The contribution to the likelihood function for individual $i$ is given by

$$
L_{i}=\int\left\{\Phi\left[\left(z_{i} \lambda+\theta \mu\right)\left(2 y_{i 1}-1\right)\right] \prod_{t=2}^{T} \Phi\left[\left(\gamma y_{i, t-1}+x_{i t} \beta+\mu\right)\left(2 y_{i t}-1\right)\right]\right\} g(\mu) \mathrm{d} \mu
$$

where $g(\mu)$ is the probability density function of the unobserved individual-specific heterogeneity and $\Phi$ denotes the standard normal cumulative distribution function. With $\mu$ taken to be normally distributed, the integral in equation (9) can be evaluated using Gaussian-Hermite quadrature (Butler and Moffitt, 1982).

In contrast to the Wooldridge model, the Heckman estimator requires additional instruments, i.e. variables affecting the initial state but, conditional on this state, without an effect on transition probabilities. Heckman (1981b) suggested that when modelling labour market outcomes, initial conditions may be instrumented by using information prior to labour market entry. Most commonly, information on the respondents' family background have been used as instruments in previous applications of the Heckman model for various labour market

\footnotetext{
${ }^{18}$ Several studies have compared the performance of the Wooldridge estimator and the Heckman estimator. Based on monte-carlo simulations and an application for unemployment persistence, Arulampalam and Stewart (2009) conclude that the results of both estimators are very similar and that neither of them outperforms the other. In contrast, Akay (2012) concludes that in short panels (below 5 waves) the Heckman estimator should be preferred because the Wooldridge estimator overestimates the true state dependence and underestimates the persistence due to unobserved time-invariant individual characteristics. Rabe-Hesketh and Skrondal (2013) attribute this conclusion to a misspecification of the Wooldridge estimator as it is used in the study by Akay. They show that biases vanish if time-averages of the explanatory variables do not include the initial period.
} 
outcomes such as unemployment (Arulampalam et al., 2000), low wage (Stewart, 2007), or social assistance receipt (Cappellari and Jenkins, 2008b). In particular, information on parental occupation, employment, or education has been used. Focusing on overqualification in Germany, Blázquez and Budría (2012) use information on the quality of the relationship with the parents as instruments. ${ }^{19}$ Mavromaras and McGuinness (2012) also rely on parental employment as instruments in their study on the state dependence of skill mismatch. Although employed by numerous studies, one could argue that family background is not an ideal instrument. In the context of overqualification, it could be assumed that the offspring from wealthy and highly educated parents obtain a higher aspiration and motivation to escape from an initial mismatch than workers with an adverse family background. ${ }^{20}$

In contrast to the previous studies, I aim to use a measure for the labour market condition at the time of the first interview as an instrument for the initial overqualification status. Recently, a line of literature has provided evidence for persistent wage penalties for workers who graduated from university during a recession (Kahn, 2010; Oreopoulos et al., 2012). For Norway, Liu et al. (2016) show that graduates are more likely to be affected by skill mismatch if they entered the labour market in a bad economy. Furthermore, they find that initially mismatched workers experience persistent negative effects on earnings and unemployment from graduating in recessions. In contrast, workers who are adequately matched in bad times do not experience significant wage penalties or higher unemployment than workers who are well-matched in the same industry in good times. From that, Liu et al. (2016) conclude that cyclical mismatch might be an important mechanism for the persistent negative effects associated with unfavourable initial labour market conditions.

The authors employ the unemployment rate at the time of graduation as a measure for initial labour market condition and argue that it captures exogenous labor demand shocks. Since the present study relies on data from only two different graduate cohorts, variation in the unemployment rate over time cannot be used as an instrument for initial conditions. ${ }^{21}$ As an alternative approach, I construct field-specific unemployment rates at the time of the first interview based on fine-grained information on the respondents' field of study. This might measure initial economic conditions affecting the probability to be overqualified, e.g. because a higher field-specific unemployment rate might force more graduates in that particular field to accept lower level jobs in order to avoid unemployment. Field-specific unemployment rates are not readily available and have been constructed as follows: Based on administrative data for Germany, the unemployment rates for tertiary graduates in 120 distinct occupations have

\footnotetext{
${ }^{19}$ In particular, Blázquez and Budría (2012) use information such as the frequency of arguments with the parents when the individual was 14 years old. The authors employ a trivariate probit model in order to take the initial condition problem into account, nevertheless the requirements concerning the instruments are the same as in the Heckman model.

${ }^{20}$ For other analysed labour market outcomes, such as low wage or unemployment, one could assume the same.

${ }^{21}$ The aggregate unemployment rate for tertiary graduates was also very similar at the time of the first interview for both cohorts, 3,1\% in 1998 and 3,3\% in 2002 (IAB, 2015).
} 
been computed. ${ }^{22}$ Merging this information to the original data set, the occupation-specific unemployment rate at the time of the first interview is given for all respondents. In the next step, the relevant labour market for each field of study is approximated by the pool of occupations held by graduates from a given field. Finally, field-specific unemployment rates are constructed by computing the unemployment rate among the entire pool of graduates in each field of the available classification differentiating 51 fields of study.

Using the field-specific unemployment rate as an instrument for the initial overqualification status in the Heckman model, the estimated coefficient was highly significant for the complete sample and the female sample but turned out to be slightly insignificant for male graduates. As an alternative, the occupation-specific unemployment rate has been used as an instrument directly. The main results concerning overqualification state dependence did not differ between both instruments. Therefore, Table 4 presents the results of the Heckman model including the occupation-specific unemployment rate as an instrument for the initial condition. ${ }^{23}$

Since estimation coefficients instead of partial effects are presented, the size of the parameters cannot be interpreted. ${ }^{24}$ The top panel of the table depicts the main panel estimation results for time periods $t=5,10$, while the bottom panel depicts the results for the initial condition equation $(t=1)$. The occupation-specific unemployment rate at the time of the first interview significantly increases the probability to be initially overqualified for both female and male graduates. Therefore, on average the risk of overqualification is higher in occupations with a lesser demand for graduates or excess supply of graduates even if some graduates select another occupation than preferred because of a currently high unemployment rate in the favourite occupation. The hypothesis of exogenous initial conditions is strongly rejected because the respective test statistic $\theta$ is significantly greater than zero. Similarly to the Wooldridge estimator, the coefficient on the lagged overqualification experience signals a significant true state dependence effect if the initial condition is jointly modelled with the subsequent periods. Furthermore, and in contrast to the Wooldridge estimator, the state dependence effect remains significant for both samples of female and male graduates.

\footnotetext{
${ }^{22}$ Data source: Sample of Integrated Labour Market Biographies (SIAB), SUF (Regional File 1975-2010). Employer information coded at the 3-digit level of the German occupational classification KldB-1988 have been aggregated to 120 occupational groups. See vom Berge et al. (2013) for further information about the data set.

${ }^{23}$ Descriptives on the occupation-specific unemployment rates are provided in Table A.5. From a theoretical view, it might have been preferred to use field-specific rather than occupation-specific unemployment rates as an instrument since the latter is prone to selection into occupations. However, the direction of selection is not clear a priori since graduates might try to bypass overqualification by avoiding occupations with a high unemployment rate. Furthermore, if similar to previous studies parental education is used as an instrument, results do not qualitatively differ from the results presented here.

${ }^{24}$ In contrast to the Wooldridge estimator, the Heckman model cannot be estimated using standard random-effects models and needs special software. For estimating the Heckman model, the redprob command for Stata is used which was also used by Stewart (2007) and can be downloaded under http://www2. warwick.ac.uk/fac/soc/economics/staff/mstewart/stata/. Since the command does not allow to estimate partial effects for the initial condition equation, only coefficients are presented in Table 4.
} 
Table 4: Results, Heckman Dynamic RE Probit

\begin{tabular}{|c|c|c|c|c|c|c|}
\hline & \multicolumn{6}{|c|}{ Dependent Variable: Overqualification } \\
\hline & \multicolumn{2}{|c|}{$\begin{array}{l}\text { All } \\
(1)\end{array}$} & \multicolumn{2}{|c|}{$\begin{array}{c}\text { Female } \\
(2)\end{array}$} & \multicolumn{2}{|c|}{$\begin{array}{c}\text { Male } \\
(3)\end{array}$} \\
\hline Overqualification $(t-5)$ & $0.333^{* * *}$ & $(0.092)$ & $0.386^{* * *}$ & $(0.127)$ & $0.303^{* *}$ & $(0.134)$ \\
\hline Female & $0.272^{* * *}$ & $(0.065)$ & & & & \\
\hline University grade & $-0.241^{* * *}$ & $(0.034)$ & $-0.267^{* * *}$ & $(0.051)$ & $-0.210^{* * *}$ & $(0.045)$ \\
\hline School grade & $-0.106^{* * *}$ & $(0.033)$ & $-0.163^{* * *}$ & $(0.051)$ & -0.064 & $(0.042)$ \\
\hline Study duration & $0.101^{* * *}$ & $(0.030)$ & $0.133^{* * *}$ & $(0.047)$ & $0.078^{*}$ & $(0.040)$ \\
\hline U. applied sciences & $0.256^{* * *}$ & $(0.068)$ & $0.257^{* *}$ & $(0.104)$ & $0.253^{* * *}$ & $(0.090)$ \\
\hline BusAdmin/Econ & ref. & & ref. & & ref. & \\
\hline Med/Law/Teaching & $-1.806^{* * *}$ & $(0.151)$ & $-2.054^{* * *}$ & $(0.228)$ & $-1.516^{* * *}$ & $(0.208)$ \\
\hline STEM subjects & $-0.739^{* * *}$ & $(0.088)$ & $-0.817^{* * *}$ & $(0.147)$ & $-0.670^{* * *}$ & $(0.111)$ \\
\hline Soc/Cult science & $-0.149^{*}$ & $(0.087)$ & $-0.246^{*}$ & $(0.128)$ & -0.051 & $(0.128)$ \\
\hline Age at grad. $<27$ & $-0.140^{* *}$ & $(0.066)$ & -0.090 & $(0.098)$ & $-0.191^{* *}$ & $(0.089)$ \\
\hline Parents high-skilled & $-0.109^{*}$ & $(0.060)$ & -0.103 & $(0.088)$ & -0.100 & $(0.079)$ \\
\hline Married & -0.034 & $(0.059)$ & -0.050 & $(0.086)$ & -0.016 & $(0.081)$ \\
\hline Children & $0.131^{* *}$ & $(0.061)$ & $0.265^{* * *}$ & $(0.089)$ & 0.013 & $(0.083)$ \\
\hline Months unemployed & $0.037^{* * *}$ & $(0.006)$ & $0.041^{* * *}$ & $(0.008)$ & $0.031^{* * *}$ & $(0.008)$ \\
\hline Constant & $-1.720^{* * *}$ & $(0.115)$ & $-1.600^{* * *}$ & $(0.172)$ & $-1.561^{* * *}$ & $(0.144)$ \\
\hline \multicolumn{7}{|c|}{ Initial Conditions Estimation } \\
\hline Female & $0.240^{* * *}$ & $(0.057)$ & & & & \\
\hline University grade & $-0.180^{* * *}$ & $(0.028)$ & $-0.137^{* * *}$ & $(0.037)$ & $-0.237^{* * *}$ & $(0.044)$ \\
\hline School grade & $-0.089^{* * *}$ & $(0.029)$ & $-0.082^{* *}$ & $(0.039)$ & $-0.098^{* *}$ & $(0.045)$ \\
\hline Study duration & $0.126^{* * *}$ & $(0.027)$ & $0.123^{* * *}$ & $(0.036)$ & $0.129^{* * *}$ & $(0.042)$ \\
\hline U. applied sciences & $0.182^{* * *}$ & $(0.061)$ & 0.030 & $(0.083)$ & $0.314^{* * *}$ & 0.094 \\
\hline BusAdmin/Econ & ref. & & ref. & & ref. & \\
\hline Med/Law/Teaching & $-1.296^{* * *}$ & $(0.102)$ & $-1.327^{* * *}$ & $(0.127)$ & $-1.366^{* * *}$ & $(0.189)$ \\
\hline STEM subjects & $-0.717^{* * *}$ & $(0.072)$ & $-0.801^{* * *}$ & $(0.107)$ & $-0.700^{* * *}$ & $(0.105)$ \\
\hline Soc/Cult science & -0.079 & $(0.082)$ & $-0.177^{*}$ & $(0.105)$ & -0.033 & $(0.140)$ \\
\hline Age at grad. $<27$ & -0.067 & $(0.059)$ & -0.023 & $(0.078)$ & -0.113 & $(0.095)$ \\
\hline Parents high-skilled & $-0.156^{* * *}$ & $(0.054)$ & $-0.116^{*}$ & $(0.070)$ & $-0.203^{* *}$ & $(0.085)$ \\
\hline Married & 0.105 & $(0.073)$ & 0.094 & $(0.099)$ & 0.136 & $(0.110)$ \\
\hline Children & 0.082 & $(0.093)$ & $0.306^{* *}$ & $(0.128)$ & -0.168 & $(0.143)$ \\
\hline Months unemployed & $0.039^{* * *}$ & $(0.011)$ & $0.043^{* * *}$ & $(0.014)$ & $0.035^{*}$ & $(0.019)$ \\
\hline Unemployment rate & $0.110^{* * *}$ & $(0.016)$ & $0.133^{* * *}$ & $(0.023)$ & $0.094^{* * *}$ & $(0.025)$ \\
\hline Constant & $-1.387^{* * *}$ & $(0.102)$ & $-1.130^{* * *}$ & $(0.137)$ & $-1.441^{* * *}$ & $(0.152)$ \\
\hline$\theta$ & 0.583 & $(0.055)$ & 0.459 & $(0.057)$ & 0.787 & $(0.121)$ \\
\hline$\rho$ & 0.622 & $(0.039)$ & 0.668 & $(0.050)$ & 0.562 & $(0.064)$ \\
\hline Log. Lik. & -6176.5 & & -3151.1 & & -3004.1 & \\
\hline Obs. Indiv. & 5987 & & 3009 & & 2978 & \\
\hline Obs. Total & 17961 & & 9027 & & 8934 & \\
\hline
\end{tabular}

Note: Random-effects probit estimation; Estimation coefficients are displayed; Standard errors in parentheses; Stata command: redprob; $\rho$ : estimate of the cross-period correlation of the composite error term $\mu_{i}+\varepsilon_{i t}$; $\theta$ : statistic used to test whether the initial conditions are exogenous. The estimate of $\theta$ is significantly greater than zero, i.e. the hypothesis that the initial conditions are exogenous is rejected; Significant at $1 \%{ }^{* * *}$, significant at $5 \%{ }^{* *}$, significant at $10 \%{ }^{*}$. 
Table 5: Results, Predicted Probabilities of Overqualification

\begin{tabular}{lccc}
\hline \hline & All & Female & Male \\
\hline Raw Data Probabilities & & & \\
\hline $\mathrm{P}\left(y_{t}=1 \mid y_{t-5}=0\right)$ & 7.9 & 8.0 & 7.8 \\
$\mathrm{P}\left(y_{t}=1 \mid y_{t-5}=1\right)$ & 52.6 & 55.2 & 49.5 \\
Difference & 44.7 & 47.2 & 41.7 \\
Wooldridge Estimator & & & \\
Predicted Probabilities & & & \\
$\mathrm{P}\left(y_{t}=1 \mid y_{t-5}=0\right)$ & 8.4 & 9.0 & 8.0 \\
$\mathrm{P}\left(y_{t}=1 \mid y_{t-5}=1\right)$ & 11.3 & 12.1 & 10.8 \\
Difference & 2.9 & 3.1 & 2.8 \\
& & & \\
Heckman Estimator & & & \\
Predicted Probabilities & & & \\
\hline $\mathrm{P}\left(y_{t}=1 \mid y_{t-5}=0\right)$ & 6.1 & 6.5 & 5.8 \\
$\mathrm{P}\left(y_{t}=1 \mid y_{t-5}=1\right)$ & 10.0 & 11.1 & 9.5 \\
Difference & 3.9 & 4.6 & 3.7 \\
\hline \hline
\end{tabular}

Note: $y_{t}$ depicts the overqualification status in time period $t$; Probabilities are predicted under the assumption that the individual heterogeneity takes its average value.

In order to assess the robustness of the estimated size of the true state dependence, Table 5 presents the average partial effect of the lagged dependent variable from the Heckman model and the Wooldridge model as well as the raw state dependence observed in the data. The average partial effects are obtained by subtracting the predicted probabilities of being overqualified conditional on the previous overqualification status under the assumption that the individualspecific heterogeneity takes its average value. The Heckman model estimate of the true state dependence effect amounts to 4 percentage points which is only slightly higher than the Wooldridge model estimate of 3 percentage points. In contrast to the Wooldridge estimator, gender differences in the rate of true state dependence are more nuanced in the Heckman model. Female graduates experience a slightly higher behavioural effect of past overqualification than male graduates but the difference amounts to less than a percentage point. Overall, the result that the true state dependence effect is much smaller than the raw state dependence of 45 percentage points is robust to the choice of econometrical models that differ in the treatment of individual-specific heterogeneity and the initial conditions problem.

\subsection{Horizontal Mismatch}

As a robustness check on the finding that unobserved factors are the main driver of observed persistence of job mismatch, this section replicates the estimation of the Wooldridge model using another measure for educational mismatch as a dependent variable (Table 6). Instead of 
Table 6: Results, Wooldridge Dynamic RE Probit, Horizontal Mismatch

\begin{tabular}{|c|c|c|c|c|c|c|}
\hline \multirow[b]{3}{*}{ Horizontal mismatch $(t-5)$} & \multicolumn{6}{|c|}{ Dependent Variable: Horizontal Mismatch } \\
\hline & \multicolumn{2}{|c|}{$\begin{array}{l}\text { All } \\
(1)\end{array}$} & \multicolumn{2}{|c|}{$\begin{array}{c}\text { Female } \\
(2)\end{array}$} & \multicolumn{2}{|c|}{$\begin{array}{c}\text { Male } \\
(3)\end{array}$} \\
\hline & $0.039^{* *}$ & $(0.017)$ & $0.044^{*}$ & $(0.025)$ & 0.033 & $(0.023)$ \\
\hline Horizontal mismatch $(t=1)$ & $0.193^{* * *}$ & $(0.023)$ & $0.159^{* * *}$ & $(0.029)$ & $0.236^{* * *}$ & $(0.038)$ \\
\hline Female & $0.011^{*}$ & $(0.006)$ & & & & \\
\hline University grade & $-0.010^{* * *}$ & $(0.003)$ & $-0.012^{* * *}$ & $(0.005)$ & $-0.009^{* *}$ & $(0.004)$ \\
\hline School grade & $-0.010^{* * *}$ & $(0.003)$ & $-0.015^{* * *}$ & $(0.005)$ & -0.006 & $(0.004)$ \\
\hline Study duration & $0.010^{* * *}$ & $(0.003)$ & $0.010^{* *}$ & $(0.005)$ & $0.011^{* *}$ & $(0.004)$ \\
\hline U. applied sciences & -0.007 & $(0.007)$ & -0.007 & $(0.011)$ & -0.008 & $(0.009)$ \\
\hline BusAdmin/Econ & ref. & & ref. & & ref. & \\
\hline Med/Law/Teach & $-0.030^{* * *}$ & $(0.009)$ & $-0.037^{* * *}$ & $(0.013)$ & $-0.030^{* *}$ & $(0.012)$ \\
\hline STEM subjects & $0.027^{* * *}$ & $(0.009)$ & 0.018 & $(0.014)$ & $0.031^{* * *}$ & $(0.011)$ \\
\hline Soc/Cult science & $0.035^{* * *}$ & $(0.012)$ & 0.019 & $(0.015)$ & $0.058^{* * *}$ & $(0.022)$ \\
\hline Age at grad. $<27$ & -0.009 & $(0.007)$ & -0.012 & $(0.010)$ & -0.006 & $(0.009)$ \\
\hline Parents high-skilled & -0.009 & $(0.006)$ & -0.003 & $(0.009)$ & $-0.015^{*}$ & $(0.008)$ \\
\hline Married & 0.003 & $(0.010)$ & -0.000 & $(0.016)$ & 0.006 & $(0.013)$ \\
\hline Children & 0.013 & $(0.011)$ & 0.010 & $(0.016)$ & 0.014 & $(0.014)$ \\
\hline Months unemployed & 0.000 & $(0.002)$ & -0.000 & $(0.002)$ & -0.001 & $(0.002)$ \\
\hline Mean: Married & -0.008 & $(0.013)$ & -0.010 & $(0.019)$ & -0.006 & $(0.018)$ \\
\hline Mean: Children & -0.010 & $(0.013)$ & 0.002 & $(0.020)$ & -0.021 & $(0.018)$ \\
\hline Mean: Months unemployed & $0.004^{* *}$ & $(0.002)$ & $0.004^{*}$ & $(0.002)$ & 0.004 & $(0.003)$ \\
\hline$\sigma$ & 1.029 & $(0.093)$ & 0.924 & $(0.122)$ & 1.161 & $(0.146)$ \\
\hline$\rho$ & 0.514 & $(0.045)$ & 0.461 & $(0.065)$ & 0.574 & $(0.062)$ \\
\hline Log Lik. & -4064.0 & & -2067.4 & & -1979.3 & \\
\hline Obs. Indiv. & 5827 & & 2914 & & 2913 & \\
\hline Obs. Total & 11654 & & 5828 & & 5826 & \\
\hline
\end{tabular}

Note: Random-effects probit estimation; Average partial effects; Standard errors in parentheses; Previous period indicated by $(t-5)$; Initial condition indicated by $(t=1) ; \rho$ : estimate of the cross-period correlation of the composite error term $a_{i}+\varepsilon_{i t}$; Significant at $1 \%^{* * *}$, significant at $5 \%^{* *}$, significant at $10 \%^{*}$.

the vertical dimension indicating whether the educational level exceeds the job requirements, this section focuses on mismatches in the educational field. Educational mismatches in the horizontal dimension may occur if graduates acquired field-specific skills and knowledge that do not match the occupational skills required for their jobs. Therefore, their stock of human capital may not be fully utilised and investments into field-specific skills do not pay off. Educational mismatches do frequently occur in both dimensions simultaneously, e.g. because few vacancies are available within a field and graduates have to downgrade to find a job. However, they represent distinct forms of educational mismatch. Individual motives and preferences may be very different for field of study mismatches than for overqualification. For instance, individuals may choose higher-paying or more career-oriented occupations outside the own field voluntarily.

Similarly to Robst (2007), I employ a subjective measure for horizontal mismatch. A dummy variable is constructed taking the value 1 if graduates indicated that their current job matches 
their field of study only to a low extent. ${ }^{25}$ In each of the three waves, roughly $16 \%$ of the graduates are horizontally mismatched (Table A.5). Conditional on the previous matching status, the probability to hold a job that is barely related to the own field amounts to $45 \%$ (9\%) for graduates who haven been previously mismatched (well-matched) in the horizontal dimension. Therefore, the raw state dependence of 36 percentage points is high but somewhat lower than the raw state dependence of overqualification. Table 6 provides the results of the Wooldridge estimator concerning the true state dependence of horizontal mismatch. For all graduates, the average partial effect of lagged horizontal mismatch is positive and significant indicating a true state dependence effect amounting to 4 percentage points. This result is very similar to the estimated true state dependence for overqualification. Gender differences concerning true state dependence are likewise small (specification 2 and 3). In line with the results for overqualification, the effect of the mismatch status in the initial period is much larger than the effect of the previous period indicating that selection into an early mismatch based on unobserved factors is highly important for the persistence.

Concerning observed heterogeneity, the results show that graduates with better grades and lower study duration are more likely to hold a job that is related to the own field of study. Signalling a high level of occupational skills by better university grades may help graduates to find suitable jobs within their field of study. This result is also in line with the previous finding that more able graduates are less likely to be overqualified.

\section{Conclusion}

In this study, I have analysed the dynamic features of overqualification over the early career cycle of tertiary graduates in Germany. The empirical analysis is based on panel data for two cohorts of graduates who participated in interviews conducted 1, 5, and 10 years after graduation. Overqualification is found to be highly persistent and to represent a permanent phenomenon for a substantial share of graduates. The probability to be overqualified is found to be 45 percentage points higher for those graduates who have already been overqualified approximately 5 years before. Accounting for a rich set of explanatory variables reduces the dynamic effect of previous overqualification experience to 34 percentage points. Therefore, raw state dependence partly arises due to observed heterogeneity affecting the probability to be overqualified at each point in time. Heterogeneity concerning study characteristics and individual ability, as measured by university and school grades, seems to be particularly relevant. Graduates with better university grades are less likely to enter or to be trapped in overqualification.

\footnotetext{
${ }^{25}$ In each wave, graduates had to indicate on a 5-point Likert-scale to what extent their current job matches their education in terms of field of study. I construct a binary indicator for horizontal mismatch taking the value 1 for all respondents opting for the Likert-values 2 and 1 ( 1 being titled "not at all").
} 
In order to analyse to what extent state dependence arises due to a behavioural effect or due to spurious correlation induced by unobserved factors, I employ the dynamic random-effects estimator proposed by Wooldridge (2005). Accounting for unobserved heterogeneity and the initial conditions problem, the results suggest that a moderate share of the overqualification persistence can be attributed to true state dependence. Previous overqualification experience is found to have a significant but small behavioural effect on future overqualification amounting to 3 percentage points. In conjunction with the finding that observed heterogeneity explains only a fraction of the persistence, these results suggest that unobserved factors are the main driver of the high persistence of overqualification. In particular, unobserved characteristics driving the selection into the initial state of overqualification are strongly related to the probability to remain overqualified later on. Such forms of unobserved heterogeneity might include preferences for particular job characteristics that can be found in low-requirement jobs, e.g. lower workload. Moreover, differences in ability that are not captured by grades may induce persistence because graduates with low ability lack the skills required to switch to an adequate job. Overall, I find little evidence for gender-specific differences in the dynamics of overqualification. Finally, the results are shown to be robust to the choice of the econometric model and the measure for educational mismatch.

Limitations of the current study may arise from the fact that only three observations per respondent are available in the data. In addition, the study does not account for a potential systematic attrition of respondents which may induce a selection of more able graduates into the estimation sample. Furthermore, the measurement of overqualification is subjective and relies on the respondents' valuation of skill requirements which is assumed to be constant over time.

The following policy implications can be drawn from this analysis. Since true state dependence explains only a small share of the overqualification persistence, policies that help avoiding or exiting overqualification are unlikely to exhibit long-lasting effects on the rate of overqualification. Policies rather need to permanently reduce barriers that prevent graduates from finding appropriate jobs matching their level of qualification. Since overqualification persistence is only partly explained by the rich set of observable characteristics included in the empirical analysis, further research is needed in order to disentangle which further barriers could contribute to the overqualification persistence.

The study shows that the field of study is an important determinant of overqualification over the first ten years of the career cycle. Therefore, a further implication is that the need for policy measures to reduce allocation constraints might differ across fields of study. By far the lowest incidence of overqualification is found for graduates in Medicine, Law, and Teaching who have to take a state examination which is a prerequisite for holding a civil service job or a job regulated by the state. These graduates will act on a highly specialised labour market narrowly focused on their own profession. The demand for graduates seems to be sufficiently high in these fields so that constrained options do not result in a high risk of overqualification. In 
contrast, allocation processes might be more difficult in the other fields leading to a higher share of mismatched graduates. A comparably low rate of overqualification among STEM graduates could be explained by the high demand for their field-specific skills. These skills are deemed to be highly important for innovation and technical developments as drivers of economic growth. In the light of the public debate about a potential shortage of STEM graduates, targeted measures could help to reconcile the actual available supply and the high demand for STEM graduates. The higher incidence of overqualification in Business Administration, Economics, Social and Cultural Sciences raises the question whether the demand for tertiary graduates in these fields is sufficiently high in order to absorb the increasing supply. Even after 10 years of labour market experience, more than one fifth of the graduates in these fields have not found a formally adequate job. Whether policies should focus on supporting a better match after course completion or should try to attract more applicants to other fields of study with lower rates of overqualification requires further research. In particular, policies aiming to attract more applicants for, e.g., STEM subjects have to be based on studies which account for potential self-selection into fields of study. 


\section{Appendix}

Table A.1: Patterns of Overqualification

\begin{tabular}{|c|c|c|c|c|c|}
\hline \multicolumn{3}{|c|}{$\begin{array}{l}\text { Patterns of Overqualification } \\
0 \text { : Matched; } 1 \text { : Overqualified }\end{array}$} & \multirow{2}{*}{$\begin{array}{c}\text { All } \\
\text { graduates }\end{array}$} & \multirow{2}{*}{$\begin{array}{c}\text { Matched } \\
\text { in } t=1 \\
\text { Percent }\end{array}$} & \multirow{2}{*}{$\begin{array}{l}\text { Overqualified } \\
\text { in } t=1 \\
\text { Percent }\end{array}$} \\
\hline$t=1$ & $t=5$ & $t=10$ & & & \\
\hline 0 & 0 & 0 & 71.5 & 86.0 & \\
\hline 0 & 1 & 0 & 4.5 & 5.5 & \\
\hline 0 & 0 & 1 & 3.7 & 4.4 & \\
\hline 0 & 1 & 1 & 3.5 & 4.2 & \\
\hline 1 & 0 & 0 & 6.9 & & 41.0 \\
\hline 1 & 1 & 0 & 2.8 & & 16.9 \\
\hline 1 & 0 & 1 & 1.5 & & 8.9 \\
\hline \multirow[t]{2}{*}{1} & 1 & 1 & 5.6 & & 33.2 \\
\hline & & & 100 & 100 & 100 \\
\hline
\end{tabular}

Table A.2: Transition Matrices

\begin{tabular}{|c|c|c|c|c|}
\hline \multirow[t]{4}{*}{ From $t=1$ to $t=5:$} & & \multicolumn{3}{|c|}{ Status in $t=5$} \\
\hline & & Matched & Overqualified & Total \\
\hline & $\begin{array}{l}\text { Status in } t=1 \\
\text { Matched } \\
\text { Overqualified }\end{array}$ & $\begin{array}{l}90.4 \\
49.9 \\
\end{array}$ & $\begin{array}{c}9.7 \\
50.1 \\
\end{array}$ & $\begin{array}{l}100 \\
100 \\
\end{array}$ \\
\hline & Raw state depe & idence & 40.4 & \\
\hline \multirow[t]{4}{*}{ From $t=5$ to $t=10:$} & & \multicolumn{2}{|c|}{ Status in $t=10$} & \\
\hline & & Matched & Overqualified & Total \\
\hline & $\begin{array}{l}\text { Status in } t=5 \\
\text { Matched } \\
\text { Overqualified }\end{array}$ & $\begin{array}{l}93.8 \\
44.9 \\
\end{array}$ & $\begin{array}{c}6.2 \\
55.1 \\
\end{array}$ & $\begin{array}{l}100 \\
100 \\
\end{array}$ \\
\hline & Raw state depe & idence & 48.9 & \\
\hline
\end{tabular}

Note: Number of observations is 5,$987 ; t$ depicts the time of observation 1,5 , and 10 years after graduation; Source: HIS-Graduate Panel 1997, 2001 
Table A.3: Incidence of Overqualification by Subgroups

\begin{tabular}{lcccc}
\hline \hline & $t=1$ & $t=5$ & $t=10$ & Total \\
\hline Gender: & & & & \\
\hline Females & 18.6 & 17.5 & 15.5 & 17.2 \\
Males & 14.9 & 15.4 & 12.9 & 14.4 \\
Field of study: & & & & \\
\hline BusAdmin/Econ & 28.7 & 28.4 & 25.6 & 27.5 \\
Med/Law/Teach & 4.8 & 3.5 & 4.0 & 4.1 \\
STEM subjects & 13.1 & 14.5 & 12.2 & 13.3 \\
Soc/cult sciences & 30.7 & 27.4 & 22.1 & 26.7 \\
University grade: & & & & \\
\hline 1. Quartile (Lowest Grades) & 23.2 & 23.0 & 19.1 & 21.7 \\
2. Quartile & 18.9 & 19.1 & 16.2 & 18.1 \\
3. Quartile & 15.1 & 13.5 & 12.7 & 13.8 \\
4. Quartile (Highest Grades) & 9.8 & 10.1 & 8.7 & 9.5 \\
\hline \hline Note: Number of observations & & & & \\
\hline
\end{tabular}

Note: Number of observations is 5,$987 ; t$ depicts the time of observation 1 , 5, and 10 years after graduation; Source: HIS-Graduate Panel 1997, 2001

Table A.4: Results, Wooldridge Dynamic RE Probit, Robustness

\begin{tabular}{|c|c|c|c|c|c|c|}
\hline \multirow[b]{3}{*}{ Overqualification $(t-5)$} & \multicolumn{6}{|c|}{ Dependent Variable: Overqualification } \\
\hline & \multicolumn{2}{|c|}{ (1) } & \multicolumn{2}{|c|}{$(2)$} & \multicolumn{2}{|c|}{$(3)$} \\
\hline & $0.029^{* *}$ & $(0.014)$ & $0.028^{* *}$ & $(0.014)$ & $0.032^{* *}$ & $(0.015)$ \\
\hline Overqualification $(t=1)$ & $0.234^{* * *}$ & $(0.024)$ & $0.237^{* * *}$ & $(0.024)$ & $0.317^{* * *}$ & $(0.030)$ \\
\hline Female & $0.019^{* * *}$ & $(0.006)$ & $0.023^{* * *}$ & $(0.007)$ & $0.013^{* *}$ & $(0.006)$ \\
\hline University grade & $-0.019^{* * *}$ & $(0.003)$ & $-0.019^{* * *}$ & $(0.003)$ & & \\
\hline School grade & $-0.008^{* *}$ & $(0.003)$ & $-0.009^{*}$ & $(0.003)$ & & \\
\hline Age at grad. $<27$ & -0.011 & $(0.007)$ & $-0.012^{*}$ & $(0.007)$ & $-0.025^{* * *}$ & $(0.006)$ \\
\hline Parents high-skilled & -0.006 & $(0.006)$ & -0.006 & $(0.006)$ & $-0.016^{* * *}$ & $(0.006)$ \\
\hline Married & -0.003 & $(0.010)$ & -0.003 & $(0.010)$ & -0.003 & $(0.009)$ \\
\hline Children & 0.007 & $(0.010)$ & 0.007 & $(0.010)$ & 0.006 & $(0.009)$ \\
\hline Months unemployed & 0.001 & $(0.001)$ & & & 0.001 & $(0.001)$ \\
\hline Married $(t=5)$ & 0.003 & $(0.010)$ & & & & \\
\hline Children $(t=5)$ & 0.006 & $(0.009)$ & & & & \\
\hline Months unemp $(t=5)$ & -0.003 & $(0.010)$ & & & & \\
\hline Married $(t=10)$ & 0.000 & $(0.009)$ & & & & \\
\hline Children $(t=10)$ & 0.002 & $(0.002)$ & & & & \\
\hline Months unemp $(t=10)$ & 0.001 & $(0.001)$ & & & & \\
\hline Mean: Married & & & 0.006 & $(0.013)$ & -0.004 & $(0.012)$ \\
\hline Mean: Children & & & 0.009 & $(0.013)$ & 0.008 & $(0.012)$ \\
\hline Mean: Months unemp & & & & & $0.004^{* *}$ & $(0.002)$ \\
\hline Study charact. & Yes & & Yes & & No & \\
\hline$\sigma$ & 1.201 & $(0.101)$ & 1.217 & $(0.101)$ & 1.252 & $(0.104)$ \\
\hline$\rho$ & 0.590 & $(0.041)$ & 0.597 & $(0.040)$ & 0.610 & $(0.040)$ \\
\hline Log. Lik. & -3827.0 & & -3849.4 & & -3983.6 & \\
\hline Obs. Indiv. & 5987 & & 5987 & & 5987 & \\
\hline Obs. Total & 11974 & & 11974 & & 11974 & \\
\hline
\end{tabular}

Note: Random-effects probit estimation; Average partial effects; Standard errors in parentheses; Previous period indicated by $(t-5)$; Initial condition indicated by $(t=1)$; $\rho$ : estimate of the cross-period correlation of the composite error term $a_{i}+\varepsilon_{i t}$; Significant at $1 \%^{* * *}$, significant at $5 \%^{* *}$, significant at $10 \%{ }^{*}$. 
Table A.5: Summary Statistics, Additional Variables

\begin{tabular}{lccccc}
\hline \hline & Mean & SD & Min & Max & $N$ \\
\hline Unemployment rate $(t=1)$ & 3.74 & 1.64 & 1.05 & 16.48 & 5987 \\
Horizontal mismatch $(t=1)$ & 0.16 & 0.37 & 0 & 1 & 5827 \\
Horizontal mismatch $(t=5)$ & 0.16 & 0.37 & 0 & 1 & 5827 \\
Horizontal mismatch $(t=10)$ & 0.14 & 0.34 & 0 & 1 & 5827 \\
\hline \hline
\end{tabular}

Source: $t$ depicts the time of observation 1, 5, and 10 years after graduation; HISGraduate Panel 1997, 2001 


\section{References}

Abel, J. R. and R. Deitz (2015). "Agglomeration and Job Matching Among College Graduates". Regional Science and Urban Economics, 51: 14-24.

Akay, A. (2012). "Finite-sample Comparison of Alternative Methods for Estimating Dynamic Panel Data Models". Journal of Applied Econometrics, 27(7): 1189-1204.

Alba-Ramirez, A. (1993). "Mismatch in the Spanish Labor Market: Overeducation?" Journal of Human Resources, 28(2): 259-278.

Albrecht, J. and S. Vroman (2002). "A Matching Model with Endogenous Skill Requirements". International Economic Review, 43(1): 283-305.

Almlund, M., A. L. Duckworth, J. Heckman, and T. Kautz (2011). "Personality Psychology and Economics". In: Handbook of the Economics of Education. Ed. by A. E. Hanushek, S. Machin, and L. Woessmann. Vol. 4. Amsterdam: Elsevier, pp. 1-181.

Arulampalam, W., A. L. Booth, and M. P. Taylor (2000). "Unemployment Persistence". Oxford Economic Papers, 52(1): 24-50.

Arulampalam, W. and M. B. Stewart (2009). "Simplified Implementation of the Heckman Estimator of the Dynamic Probit Model and a Comparison with Alternative Estimators". Oxford Bulletin of Economics and Statistics, 71(5): 659-681.

Baert, S., B. Cockx, and D. Verhaest (2013). "Overeducation at the Start of the Career: Stepping Stone or Trap?" Labour Economics, 25: 123-140.

Battu, H., C. R. Belfield, and P. J. Sloane (1999). "Overeducation Among Graduates: A Cohort View". Education Economics, 7(1): 21-38.

Becker, G. (1964). Human Capital. New York: Columbia University Press.

Berlingieri, F. and D. Erdsiek (2012). How Relevant is Job Mismatch for German Graduates? ZEW Discussion Paper No. 12-075. Mannheim.

Biewen, M. (2009). "Measuring State Dependence in Individual Poverty Histories when There is Feedback to Employment Status and Household Composition". Journal of Applied Econometrics, 24(7): 1095-1116.

Blázquez, M. and S. Budría (2012). "Overeducation Dynamics and Personality". Education Economics, 20(3): 260-283. 
Boll, C., J. S. Leppin, and K. Schömann (2016). "Who is Overeducated and Why? Probit and Dynamic Mixed Multinomial Logit Analyses of Vertical Mismatch in East and West Germany". Education Economics, 24(6): 639-662.

Borghans, L. and A. de Grip (2000). "The Debate in Economics About Skill Utilization”. In: The Overeducated Worker?: The Economics of Skill Utilization. Ed. by L. Borghans and A. de Grip. Cheltenham: Edward Elgar Publishing, pp. 3-23.

Büchel, F. (2002). "The Effects of Overeducation on Productivity in Germany - The Firms' Viewpoint". Economics of Education Review, 21(3): 263-275.

Büchel, F. and H. Battu (2003). "The Theory of Differential Overqualification: Does It Work?" Scottish Journal of Political Economy, 50(1): 1-16.

Büchel, F. (2001). "Overqualification: Reasons, Measurement Issues, and Typological Affinity to Unemployment". In: Training in Europe: Second Report on Vocational Training Research in Europe 2000: Background Report. Ed. by P. Descy and M. Tessaring. Luxembourg: Office for Official Publications of the European Communities, pp. 453-560.

Büchel, F. and A. Mertens (2004). "Overeducation, Undereducation, and the Theory of Career Mobility". Applied Economics, 36(8): 803-816.

Büchel, F. and M. Pollmann-Schult (2004). "Overeducation and Human Capital Endowments". International Journal of Manpower, 25(2): 150-166.

Büchel, F. and M. Van Ham (2003). "Overeducation, Regional Labor Markets, and Spatial Flexibility". Journal of Urban Economics, 53(3): 482-493.

Burdett, K. (1978). "A Theory of Employee Job Search and Quit Rates". American Economic Review, 68(1): 212-220.

Butler, J. S. and R. Moffitt (1982). "A Computationally Efficient Quadrature Procedure for the One-Factor Multinomial Probit Model". Econometrica, 50(3): 761-64.

Cappellari, L. and S. P. Jenkins (2008a). "Estimating Low Pay Transition Probabilities Accounting for Endogenous Selection Mechanisms". Journal of the Royal Statistical Society: Series C (Applied Statistics), 57(2): 165-186.

Cappellari, L. and S. P. Jenkins (2008b). The Dynamics of Social Assistance Receipt: Measurement and Modelling Issues, with an Application to Britain. IZA Working Paper No. 3765. Bonn. 
Caroli, E. and J. Van Reenen (2001). "Skill-Biased Organizational Change? Evidence from a Panel of British and French Establishments". Quarterly Journal of Economics, 116(4): 1449-1492.

Cedefop (2012). Skill Mismatch - The Role of the Enterprise. Luxembourg: Publications Office of the European Union.

Chamberlain, G. (1984). "Panel Data". In: Handbook of Econometrics. Ed. by Z. Griliches and M. D. Intriligator. Vol. 2. Amsterdam: Elsevier, pp. 1247-1318.

Chay, K. Y. and D. R. Hyslop (2014). "Identification and Estimation of Dynamic Binary Response Panel Data Models: Empirical Evidence Using Alternative Approaches". In: Safety Nets and Benefit Dependence. Ed. by S. Carcillo, H. Immervoll, S. P. Jenkins, S. Königs, and K. Tatsiramos. Somerville, MA: Emerald Group Publishing, pp. 1-39.

Chevalier, A. (2003). "Measuring Over-Education". Economica, 70(279): 509-531.

Chevalier, A. and J. Lindley (2009). "Overeducation and the Skills of UK Graduates". Journal of the Royal Statistical Society: Series A, 172(2): 307-337.

Clark, B., C. Joubert, and A. Maurel (2014). The Career Prospects of Overeducated Americans. NBER Working Paper No. 20167. Cambridge, MA.

De Grip, A., H. Bosma, D. Willems, and M. Van Boxtel (2008). "Job-Worker Mismatch and Cognitive Decline". Oxford Economic Papers, 60(2): 237-253.

Desjardins, R. and K. Rubenson (2011). An Analysis of Skill Mismatch Using Direct Measures of Skills. OECD Education Working Papers No. 63. Paris.

Doeringer, P. B. and M. J. Piore (1971). Internal Labor Markets and Manpower Analysis. Lanham: Heath Lexington Books.

Dolado, J., M. Jansen, and J. Jimeno (2009). "On-the-Job Search in a Matching Model with Heterogeneous Jobs and Workers". Economic Journal, 119(534): 200-228.

Dolton, P. and A. Vignoles (2000). "The Incidence and Effects of Overeducation in the UK Graduate Labour Market". Economics of Education Review, 19(2): 179-198.

Duncan, G. and S. Hoffman (1981). "The Incidence and Wage Effects of Overeducation". Economics of Education Review, 1(1): 75-86.

Erdsiek, D. (2016). "Overqualification of Graduates: Assessing the Role of Family Background". Journal for Labour Market Research, 49(3): 253-268. 
European Commission (2010). EUROPE 2020: A Strategy for Smart, Sustainable and Inclusive Growth. Brussels: Publications Office of the European Union.

Fabian, G. and K. Briedis (2009). "Aufgestiegen und Erfolgreich: Ergebnisse der Dritten HISAbsolventenbefragung des Jahrgangs 1997 Zehn Jahre nach dem Examen”. In: HIS: Forum Hochschule. No. 2. Hannover: DZHW.

Fabian, G., T. Rehn, G. Brandt, and K. Briedis (2013). "Karriere mit Hochschulabschluss". In: HIS: Forum Hochschule. No. 10. Hannover: DZHW.

Feenstra, R. C. and G. H. Hanson (1999). "The Impact of Outsourcing and High-Technology Capital on Wages: Estimates for the United States, 1979-1990". Quarterly Journal of Economics, 114(3): 907-940.

Fitzenberger, B., S. Steffes, and A. Strittmatter (2016). "Return-to-Job During and After Parental Leave". International Journal of Human Resource Management, 27(8): 803-831.

Frank, R. (1978). "Why Women Earn Less: The Theory and Estimation of Differential Overqualification". American Economic Review, 68(3): 360-373.

Frenette, M. (2004). "The Overqualified Canadian Graduate: The Role of the Academic Program in the Incidence, Persistence, and Economic Returns to Overqualification". Economics of Education Review, 23(1): 29-45.

Gautier, P. A. and C. N. Teulings (2015). "Sorting and the Output Loss due to Search Frictions". Journal of the European Economic Association, 13(6): 1136-1166.

Green, F. and S. McIntosh (2007). "Is There a Genuine Under-Utilization of Skills Amongst the Over-Qualified". Applied Economics, 39(4): 427-439.

Green, F. and Y. Zhu (2010). "Overqualification, Job Dissatisfaction, and Increasing Dispersion in the Returns to Graduate Education". Oxford Economic Papers, 62(4): 740-763.

Hartog, J. (2000). "Over-Education and Earnings: Where are We, Where Should We Go?" Economics of Education Review, 19(2): 131-147.

Hartog, J. (1986). "Allocation and the Earnings Function". Empirical Economics, 11(2): 97-110.

Heckman, J. J. (1981a). "Heterogeneity and State Dependence". In: Studies in Labor Markets. Ed. by S. Rosen. Chicago, IL: University of Chicago Press, pp. 91-140.

Heckman, J. J. (1981b). "The Incidental Parameters Problem and the Problem of Initial Conditions in Estimating a Discrete Time-Discrete Data Stochastic Process." In: Structural Analysis of Discrete Data and Econometric Applications. Ed. by C. Manski and D. McFadden. Cambridge: MIT Press, pp. 179-195. 
Heckman, J. J. and G. J. Borjas (1980). "Does Unemployment Cause Future Unemployment? Definitions, Questions and Answers from a Continuous Time Model of Heterogeneity and State Dependence". Economica, 47(187): 247-283.

Holzer, H. J. (1987). "Job Search by Employed and Unemployed Youth". Industrial Es Labor Relations Review, 40(4): 601-611.

IAB (2015). Qualifikationsspezifische Arbeitslosenquoten. Aktuelle Daten und Indikatoren. Nürnberg: Institut für Arbeitsmarkt- und Berufsforschung.

Jovanovic, B. (1979). "Job Matching and the Theory of Turnover". Journal of Political Economy, 87(5): 972-990.

Kahn, L. B. (2010). "The Long-Term Labor Market Consequences of Graduating from College in a Bad Economy". Labour Economics, 17(2): 303-316.

Kampelmann, S. and F. Rycx (2012). "The Impact of Educational Mismatch on Firm Productivity: Evidence from Linked Panel Data". Economics of Education Review, 31(6): 918931.

Kiersztyn, A. (2013). "Stuck in a Mismatch? The Persistence of Overeducation During Twenty Years of the Post-Communist Transition in Poland". Economics of Education Review, 32: $78-91$.

Kleibrink, J. (2015). "Inept or Badly Matched? - Effects of Educational Mismatch in the Labor Market". LABOUR, 30(1): 88-108.

Korpi, T. and M. Tåhlin (2009). "Educational Mismatch, Wages, and Wage Growth: Overeducation in Sweden, 1974-2000". Labour Economics, 16(2): 183-193.

Kroft, K., F. Lange, M. J. Notowidigdo, et al. (2013). "Duration Dependence and Labor Market Conditions: Evidence from a Field Experiment". Quarterly Journal of Economics, 128(3): $1123-1167$.

Krusell, P., L. E. Ohanian, J.-V. Ríos-Rull, and G. L. Violante (2000). "Capital-Skill Complementarity and Inequality: A Macroeconomic Analysis". Econometrica, 68(5): 1029-1053.

Leuven, E. and H. Oosterbeek (2011). "Overeducation and Mismatch in the Labor Market". In: Handbook of the Economics of Education. Ed. by A. E. Hanushek, S. Machin, and L. Woessmann. Vol. 4. Amsterdam: Elsevier, pp. 283-326.

Liu, K., K. G. Salvanes, and E. Ø. Sørensen (2016). "Good Skills in Bad Times: Cyclical Skill Mismatch and the Long-term Effects of Graduating in a Recession". European Economic Review, 84: 3-17. 
Mahy, B., F. Rycx, and G. Vermeylen (2015). "Educational Mismatch and Firm Productivity: Do Skills, Technology and Uncertainty Matter?" De Economist, 163(2): 233-262.

Mavromaras, K. and S. McGuinness (2012). "Overskilling Dynamics and Education Pathways". Economics of Education Review, 31(5): 619-628.

McCormick, B. (1990). "A Theory of Signalling During Job Search, Employment Efficiency, and "Stigmatised" Jobs". Review of Economic Studies, 57(2): 299-313.

McGowan, M. A. and D. Andrews (2015). Labour Market Mismatch and Labour Productivity: Evidence from PIAAC Data. OECD Economics Department Working Papers No. 1209. Paris.

McGuinness, S. and P. J. Sloane (2011). "Labour Market Mismatch Among UK Graduates: An Analysis Using REFLEX Data". Economics of Education Review, 30(1): 130-145.

Michaels, G., A. Natraj, and J. Van Reenen (2014). "Has ICT Polarized Skill Demand? Evidence from Eleven Countries over Twenty-Five Years". Review of Economics and Statistics, 96(1): $60-77$.

Mincer, J. (1974). Schooling, Experience and Earnings. New York: Columbia University Press.

Mundlak, Y. (1978). "On the Pooling of Time Series and Cross Section Data". Econometrica, 46(1): $69-85$.

Oreopoulos, P., T. Von Wachter, and A. Heisz (2012). "The Short- and Long-Term Career Effects of Graduating in a Recession". American Economic Journal: Applied Economics, 4(1): $1-29$.

Pissarides, C. A. (1994). "Search Unemployment with On-The-Job Search". Review of Economic Studies, 61(3): 457-475.

Poropat, A. E. (2009). "A Meta-Analysis of the Five-Factor Model of Personality and Academic Performance". Psychological Bulletin, 135(2): 322.

Rabe-Hesketh, S. and A. Skrondal (2013). "Avoiding Biased Versions of Wooldridge's Simple Solution to the Initial Conditions Problem". Economics Letters, 120(2): 346-349.

Robst, J. (2007). "Education and Job Match: The Relatedness of College Major and Work". Economics of Education Review, 26(4): 397-407.

Sattinger, M. (1993). "Assignment Models of the Distribution of Earnings". Journal of Economic Literature, 31(2): 831-880.

Sattinger, M. (2012). "Qualitative Mismatches". Foundations and Trends in Microeconomics, 8(1-2): 1-168. 
Scherer, S. (2004). "Stepping-Stones or Traps? The Consequences of Labour Market Entry Positions on Future Careers in West Germany, Great Britain and Italy". Work, Employment E Society, 18(2): 369-394.

Sicherman, N. and O. Galor (1990). "A Theory of Career Mobility". Journal of Political Economy, 98(1): 169-92.

Sicherman, N. (1991). "Overeducation in the Labor Market". Journal of Labor Economics, 9(2): $101-122$.

Stewart, M. B. (2007). "The Interrelated Dynamics of Unemployment and Low-Wage Employment". Journal of Applied Econometrics, 22(3): 511-531.

Stewart, M. B. and J. K. Swaffield (1999). "Low Pay Dynamics and Transition Probabilities". Economica, 66(261): 23-42.

Teulings, C. N. and P. A. Gautier (2004). "The Right Man for the Job". Review of Economic Studies, 71(2): 553-580.

Thurow, L. C. (1972). "Education and Economic Equality". The Public Interest, 28: 66-81.

Tsai, Y. (2010). "Returns to Overeducation: A Longitudinal Analysis of the US Labor Market". Economics of Education Review, 29(4): 606-617.

Verhaest, D. and R. van der Velden (2012). "Cross-Country Differences in Graduate Overeducation". European Sociological Review, 29(3): 642-653.

vom Berge, P., A. Burghardt, and S. Trenkle (2013). Sample-of-Integrated-Labour-MarketBiographies Regional-File 1975-2010 (SIAB-R 7510). Documentation on Labour Market Data No. 09/2013. Nürnberg: Institut für Arbeitsmarkt- und Berufsforschung.

Wooldridge, J. M. (2000). "A Framework for Estimating Dynamic, Unobserved Effects Panel Data Models with Possible Feedback to Future Explanatory Variables". Economics Letters, 68(3): 245-250.

Wooldridge, J. M. (2005). "Simple Solutions to the Initial Conditions Problem in Dynamic, Nonlinear Panel Data Models with Unobserved Heterogeneity". Journal of Applied Econometrics, 20(1): 39-54. 